\title{
Ecophysiology of the cacao tree
}

\author{
Alex-Alan F. de Almeida ${ }^{1 *}$ and Raúl R. Valle Val, $^{1,2}$ \\ ${ }^{1}$ Departamento de Ciências Biológicas, Universidade Estadual de Santa Cruz, 45662-000 Ilhéus, BA, Brasil. ${ }^{2}$ Centro \\ de Pesquisas do Cacau, CEPLAC, C.P. 07, 45650-000 Ilhéus, BA, Brasil, raul@cepec.gov; br. *Corresponding author: \\ alexalan@uesc.br
}

Received: 31 October 2007; Accepted: 28 February 2008

Cacao, one of the world's most important perennial crops, is almost exclusively explored for chocolate manufacturing. Most сасаo varieties belong to three groups: Criollo, Forastero and Trinitario that vary according to morphology, genetic and geographical origins. It is cropped under the shade of forest trees or as a monocrop without shade. Seedlings initially show an orthotropic growth with leaf emission relatively independent of climate. The maturity phase begins with the emission of plagiotropic branches that form the tree crown. At this stage environmental factors exert a large influence on plant development. Growth and development of cacao are highly dependent on temperature, which mainly affects vegetative growth, flowering and fruit development. Soil flooding decreases leaf area, stomatal conductance and photosynthetic rates in addition to inducing formation of lenticels and adventitious roots. For most genotypes drought resistance is associated with osmotic adjustment. Cacao produces caulescent flowers, which begin dehiscing in late afternoon and are completely open at the beginning of the following morning releasing pollen to a receptive stigma. Non pollinated flowers abscise 24-36 h after anthesis. The percentage of flowers setting pods is in the range 0.5 - 5\%. The most important parameters determinants of yield are related to: (i) light interception, photosynthesis and capacity of photoassimilate distribution, (ii) maintenance respiration and (iii) pod morphology and seed fermentation, events that can be modified by abiotic factors. Cacao is a shade tolerant species, in which appropriate shading leads to relatively high photosynthetic rates, growth and seed yield. However, heavy shade reduces seed yield and increases incidence of diseases; in fact, cacao yields and light interception are tightly related when nutrient availability is not limiting. High production of non-shaded cacao requires high inputs in protection and nutrition of the crop. Annual radiation and rainfall during the dry season explains $70 \%$ of the variations in annual seed yields.

Key words: root growth, flowering, pod set, flushing, mineral nutrition

Ecofisiologia do cacaueiro: O cacau, um dos mais importantes cultivos perenes no mundo, é quase exclusivamente explorado para a fabricação de chocolate. A maioria das variedades de cacau pertence a três grupos: Criollo, Forasteiro e Trinitário, que variam de acordo com a morfologia, genética e origem geográfica. É cultivado sob sombra de árvores de floresta ou como monocultivo sem sombra. As plântulas inicialmente mostram um crescimento ortotrópico com emissão de folhas relativamente independente do clima. A fase de maturidade inicia-se com a emissão de ramos plagiotrópicos que formam a copa. Nesse estádio, fatores ambientes exercem grande influência no desenvolvimento da planta. O crescimento e o desenvolvimento do cacaueiro são dependentes da temperatura, que afeta principalmente o crescimento vegetativo, florescimento e desenvolvimento do fruto. O alagamento do solo diminui a área folhar, a condutância estomática e taxa de fotossíntese, além de induzir a formação de lenticelas e raízes adventícias. Para a maioria dos genótipos a resistência à seca é associada ao ajustamento osmótico. O cacau produz flores caulescentes que começam sua deiscência à tarde e se abrem completamente no início da manhã seguinte com liberação de pólen para um estigma receptivo. Flores não polinizadas sofrem abscisão 24-36 h após a antese. A porcentagem de flores que se transforma em frutos é de 0,5 - 5\%. Os mais importantes parâmetros determinantes do rendimento estão relacionados com: (i) interceptação da luz, fotossíntese e capacidade de distribuição de fotoassimilados, (ii) respiração de manutenção e (iii) morfologia do fruto e fermentação das sementes, eventos que podem ser modificados por fatores abióticos. 
Sombreamento pesado reduz a produção de sementes e aumenta a incidência de doenças. O cacau é uma espécie tolerante a sombra, no qual o sombreamento apropriado pode resultar em taxas fotossintéticas relativamente altas, crescimento e produção de sementes. No entanto, quando a disponibilidade de nutrientes minerais não é limitante, há uma correlação positiva entre produção de cacau e interceptação de luz. A alta produção de cacau a pleno sol requer maiores investimentos em proteção e nutrição do cultivo. A radiação anual e precipitação durante a estação seca explicam $70 \%$ das variações na produção anual de sementes.

Palavras-chave: crescimento radicular, florescimento, frutificação, lançamento foliar, nutrição mineral

\section{INTRODUCTION}

Cacao (Theobroma cacao L.) is a preferentially alogamous tropical woody species formerly in the Sterculiaceae family (Cuatrecasas, 1964) and reclassified in the Malvaceae family (Alverson et al., 1999). Under natural conditions the tree can reach 20 to $25 \mathrm{~m}$ in height (Lachenaud et al., 1997), whereas under cultivation it varies from 3 to $5 \mathrm{~m}$. The geographical origin of cacao is South America (Motamayor et al., 2002), where several wild populations can be found in the Amazon and Guyanian regions. It is considered one of the most important perennial crops in the planet, with an estimated world output of 3.5 millions tons in 2006 (ICCO, 2007). It is predominantly grown in the tropical areas of Central and South America, Asia and Africa (Marita et al., 2001). Cacao is commercially exploited for seed output mainly destined for chocolate manufacturing. However, derivatives and byproducts of cacao can also be transformed in cosmetics, fine beverages, jellies, ice creams and juices.

Traditionally cropped cacao varieties belong to three main groups named Criollo, Forastero and Trinitario, according to morphology and genetic characteristics and geographical origins (Bartley, 2005). The cacao Criollo has been cultivated for a long time in Central and South America and constitutes the first domesticated cacao trees (Sounigo et al., 2003). This group is comprised of varieties that produce fruits (pods) with thick, white or pinkish seeds that yield more flavored seeds and fine chocolates (Marita et al., 2001). It is, however, infrequently cultivated because of its high susceptibility to diseases (Soria, 1970). Varieties of the Forastero group are widely cropped due to their high yields and resistance to diseases. They produce around $80 \%$ of the world output of cacao seeds (Marita et al., 2001). This group is subdivided into Lower and Upper Amazonian Forasteros; the former are cultivated in the Amazon Basin and their cultivars were the first to be introduced in Africa, while the latter are considered more genetically diversified and frequently used in breeding programs due to their vigor, precocity and disease resistance (Iwaro et al., 2001). The first Forastero varieties originated from the lower Amazon basin and were cultivated mainly in Brazil and Venezuela (Sounigo et al., 2003). The Trinitarios are considered recent hybrids originated from crosses between Criollos and Lower Amazonian Forastero genotypes or intermediate types (Motamayor, 2001).

Traditionally, cacao is cultivated under the shade of a selectively thinned forest (Lobão et al., 2007) and represents one of the oldest agroforestry systems in tropical America, known since pre-Colombians times by the Mayas (Bergman, 1969). In the Atlantic coastal forests of the states of Bahia and Espirito Santo, Brazil, around $4 \%$ of the world and $75 \%$ of the Brazilian cacao output is obtained using a system locally called Cabruca (Lobão et al., 2007). This system is a special kind of agroforestry in which the understorey is drastically suppressed to introduce cacao and the density of upper storey trees is reduced (Lobão et al., 2007). Cacao cultivation in this form shows much of the sustainability attributes of the natural heterogeneous forest, being considered the most efficient plant community for protection of tropical soils against degradation agents (Alvim, 1989b).

Cacao is also intercropped around the world in planned systems with other species of economic value like Areca catechu, Cocos nucifera (Daswir and Dja'far, 1988; Abbas and Dja' far, 1989; Liyanage 1985; Alvim and Nair 1986), Hevea brasiliensis, Syzigium aromaticum, Cinnamomum zeylanicum, Erythrina fusca (Alvim, 1989a; Alvim, 1989b), Bactris gasipaes (Almeida et al., 2002a) and other Amazonian species (Brito et al., 2002). Several agroforestry systems use more than three species 
in planned associations (Müller and Gama Rodrigues, 2007). In contrast, cocoa is also cropped under unshaded conditions. In Ghana and Ivory Coast for example, 50\% of the total cacao farm area is under mild shade whilst an average of $10 \%$ in Ghana and 35\% in Ivory Coast is managed under no shade (Padi and Owusu, 1998). In a shade and fertilizer trial conducted with Amazon cacao over a 20-year period in Ghana, yield of heavily shaded plots were about half those under the non-shade treatment (Ahenkorah et al., 1987). Despite that, the authors inferred that the economic life of an unshaded Amelonado cacao farm in Ghana may not last for more than 15 years of intensive cropping. This means that cacao can be produced economically unshaded with adequate management practices and water and nutrient replenishment.

Our objective is to provide information about the effects of biotic and abiotic factors on growth and development of the cacao plant that could be useful in the design of strategies for new cropping systems. This is particularly important considering that the cacao planting frontiers are being expanded towards marginal lands in tropical and subtropical areas.

\section{EFFECTS OF ABIOTIC FACTORS ON GROWTH AND DEVELOPMENT OF CACAO SEEDLINGS}

Cacao exhibits a considerable genetic variability in morphological and physiological traits (Daymond et al., 2002a,b). When it is multiplied via seeds, initially it displays an orthotropic growth pattern exhibiting cycles of leaf flushings, in which the phyllotaxy is alternate (Vogel, 1975). Furthermore, leaf emission occurs in a rhythmic way relatively independent of climate, which indicates that the growth rhythm is under endogenous control (Vogel, 1975). However, after achieving approximately one to $1.2 \mathrm{~m}$ in height, the orthotropic growth ceases and the plant emits plagiotropic branches (Garcia and Nicolella, 1985). The number of plagiotropic branches varies from three to five, forming what is generally named the cup or crown of the cacao tree (Cuatrecasas, 1964). Also, there are inter- and intraspecific variations for the orthotropic growth pattern (Batista and Alvim, 1981; Garcia and Nicolella, 1985). Contrary to Soria (1964) and Garcia and Nicolella (1985),
Batista and Alvim (1981) verified that the genetic background of orthotropic growth is influenced by environmental factors. Environmental factors exert an influence of approximately $70 \%$ on the development of the cacao plant at this stage (Garcia, 1973).

According to Greathouse et al. (1971) and Orchard et al. (1980), the specific stages of leaf flushing in the orthotropic growth phase are: F-1 - bud swelling: leaf initiation and unfolding; F-2 - leaf expansion: thin leaves, with strong anthocyanin pigmentation and apical bud dormant; I-1 - leaf expansion complete: quick greening and apical bud dormant; I-2 - entirely expanded dark green leaves: apical bud dormant. Immediately after the emergence of the next leaf, leaves in the initial F-1 stage are red and are positioned almost vertically upwards. However, with expansion (F-2 stage) the stem:petiole angle decreases to approximately $90^{\circ}$ such that the petiole remains horizontal and, with an angle of approximately $90^{\circ}$ between the leaf blade and petiole, the blade hangs vertically downwards (Abo-Hamed et al., 1983).

During the F-2 stage the leaves are very thin and flexible. This condition is maintained during leaf expansion until they enter the stage period of fast greening (beginning of stage I-1), when the stem:petiole and leaf:petiole angles increase. Up to the moment that the leaf blade becomes completely green, it thickens and becomes rigid with a pronounced cuticle, and both the stem:petiole and leaf blade:petiole angles increase resulting in the petiole and blade being positioned almost vertically. Subsequently the petiole:leaf blade angle decreases approximately $90^{\circ}$ and the blade is positioned horizontally (lower leaves). This position is maintained for the rest of the leaf's life (Abo-Hamed et al., 1983).

Although the duration of the several stages of the flush cycle may vary depending on the growth conditions [see, for example, Greathouse et al. (1971) and Vogel (1975)] the basic development pattern is relatively fixed, that is, the beginning of the cycle is marked by swelling of the apical bud followed by unfolding of all leaves in the flush (Abo-Hamed et al., 1983). The end of leaf production and the growth limitation of subsequent leaves within a flush, which are smaller in size, are probably consequences of carbohydrate limitations, as noted by Machado and Hardwick (1987). They proposed that a new flush occurs following an interflush period in 
which the carbohydrate supply is replenished; with the return of a favorable carbohydrate balance a new leaf flush takes place.

According to Baker et al. (1975) (i) plastid length, breadth, number of grana and lamella index per plastid, as well as the number of lamella per granum increase with chlorophyll (chl) content; (ii) the number of chloroplasts per cell remains constant (three) during leaf development; (iii) lutein, neoxantin, violaxantin, $\alpha$ - and $\beta$ carotenes are the carotenoids found in measurable quantities in leaves; (iii) $\alpha$-carotene is present in slightly higher quantities than $\beta$-carotene; (iv) both xanthophylls and carotenes increase linearly with chl content during leaf development; (v) and the phase of maximum chloroplast development occurs after the end of leaf expansion. Baker and Hardwick (1973) did not observe changes in the molar relation of chl $a: b$. However, Baker and Hardwick (1974) and Baker et al. (1975) observed that (i) the photosynthetic capacity and the chl content increased in parallel during flushing; (ii) the maximum photosynthetic capacity per chl unit remains constant during chloroplast development; (iii) the saturating irradiance (SI) increases with increasing chl content; (iv) the total number of photosynthetic units increases one by one during leaf growth; (iv) the photosynthetic efficiency increases per chl unit during leaf development; (v) the thylakoid formation occurs in parallel with chl synthesis during chloroplast development; (vi) the maximum phase of chloroplast development may not occur until after the end of leaf expansion; (vii) the phase of maximum synthesis of chl coincides with the end of the linear phase of leaf expansion; (viii) Rubisco activity increases with the content of chl and can be a limiting factor for photosynthesis; and (ix) the chl content can be used as a general indicator of chloroplast development.

The apparent absence of green color in young cacao leaves is not related to the delay in chloroplast development, but is due to the fact that chloroplasts are initially very small and usually few (Whatley, 1992). The delay in greening of leaves is associated with a late increase in the total extension of the thylakoid system inside each cell that accompanies the subsequent increase in plastid size (Whatley, 1992). Lee et al. (1987) reported that the changes in color shown by cacao leaves during its ontogeny resulted in varying levels of different pigments, like anthocyanins and/or phenols that initially mask the chl content. Content of these pigments fluctuates during leaf expansion (total content of phenols remains high and that of anthocyanins decreases with maturity).

On the hypostomatous cacao leaf surface (Hardwick et al., 1981) four main kinds of hairs are found, the most common of which are thick and short, with a multicellular rounded head (Abo-Hamed et al., 1983). In 4-d-old leaves, stomata are found only in the midribs, primary lateral and minor veins, while only those of the midribs are completely developed and can open. Stomata of the secondary and lateral ribs open within 2-4 d, and those in inter-veinal regions begin to develop and can open towards the end of the leaf expansion phase (Abo-Hamed et al., 1983). According to Abo-Hamed et al. (1983) the maturation of stomata is correlated with the presence of chl. The cuticle thickness increases at a constant rate during leaf expansion achieving maximum thickness during I-1, and stomata and cuticle development follow a pattern closely correlated with the growth stages of the leaf.

Müller et al. (1992), evaluating photosynthesis in cacao leaves of different ages grown under two irradiances, found a strong effect of light intensity during leaf development on photosynthetic capacity of mature leaves. In cacao, shade leaves often exhibit greater total chl concentrations than sun leaves (Merkel et al., 1994). Ontogenetic changes in the leaf chl $a: b$ ratio is a controversial issue, as it has been shown to increase continuously (Merkel et al., 1994) or to be held in check (Baker and Hardwick, 1973, 1974) during leaf development. Costa et al. (1998), evaluating the growth of cacao seedlings under different light levels and $\mathrm{N}$ concentrations, verified increases in leaf blade thickness with the increase of light intensity, independent of $\mathrm{N}$ concentration. Under shade conditions and high $\mathrm{N}$ concentrations, they observed the spongy parenchyma with a reduced number of small cells distributed over vast intercellular spaces, while short cells constituted the palisade parenchyma, interspersed by quite large spaces.

Seedlings grow slowly under full sunlight and some degree of shade is beneficial for their establishment (Okali and Owusu, 1975). Thus, shelter trees have been invariably recommended for the establishment of cacao seedlings (Alvim, 1977), which would be gradually removed with increasing self-shade (Byrne, 1972). The 
slow growth of seedlings under full sunlight is due to constraints on leaf expansion, probably caused by excessive transpiration that would induce leaf water stress (Okali and Owusu, 1975). In contrast, shaded leaves show higher relative water content and fewer stomata per unit leaf area than unshaded leaves. According to Abo-Hamed et al. (1983), the perpendicular positioning of young leaves in the flush, the presence of superficial hairs, the rapid synthesis of cuticle and the development of stomata, limited to the initial stages of leaf expansion, restrain the water loss of developing leaves.

The saturating irradiance for photosynthesis of a mature cacao leaf varies from 6\% (Baker and Hardwick, 1973) to $30 \%$ (Okali and Owusu, 1975) of full sunlight, while for a developing leaf the SI increases with increasing chl content (Baker and Hardwick, 1976). Under SI, younger leaves (PF1) of the flush showed photosynthetic rates significantly higher than both the oldest leaves of PF2 (middle age leaves) and PF3 (old leaves) (Machado and Hardwick, 1988). Under field conditions, the total potential contribution of photosynthesis of the oldest leaves would be remarkably reduced as a consequence of mutual shading in the crown interior (Machado and Hardwick, 1988).

Cacao seedlings show increasing rates of net photosynthesis (A) as the photosynthetically active radiation (PAR) increases to values in the range from near 400 (Joly, 1988) to 750 (Da Matta et al., 2001) $\mu \mathrm{mol} \mathrm{m}^{-2} \mathrm{~s}^{-1}$, corresponding to $20-30 \%$ of PAR at full sunlight, when SI is reached. About $95 \%$ of the maximum $A$ is obtained with half SI. At full sunlight, $A$ declines at expositions above $30 \%$ of the global radiation (Okali and Owusu, 1975; Hutcheon, 1976), in which A of many plants usually reaches the maximum (Alvim, 1965). For leaves developed under shade conditions, a decrease in A occurs below $20 \%$ of full sunlight (Owusu, 1978), whereas Okali and Owusu (1975) found in shade leaves that SI occurred at around $3-4 \%$ of full sunlight. Therefore, the varying SI should be a reflection of differences in growth and measurement conditions.

Cunningham and Burridge (1960) by submitting cacao seedlings to full sunlight and heavy shading (85\%) showed that water and mineral nutrients were the most crucial factors for growth promotion at full sun exposure. According to Okali and Owusu (1975) nutrients may be more important than shading for seedling establishment. Costa et al. (1998), on growing cacao seedlings under different light levels and $\mathrm{N}$ doses, observed a significant increase in chl content of mature and more shaded leaves, especially at higher $\mathrm{N}$ doses. The increase at all irradiances tested occurred in the presence of up to 10 $\mathrm{mM}$ of $\mathrm{N}$, but above that concentration it leveled off. Okali and Owusu (1975) and Merkel et al. (1994) found similar results regarding chl content and PAR for other cacao genotypes.

For cacao plantation systems it is hypothesized that once the nutritional demands are met, the yield of the understorey crop is dependent mainly on the accessibility to solar radiation (Cunningham and Arnold, 1962). In any case, Hutcheon (1973) evaluating the growth of the cacao clone Scavina-6 and two other Amelonado genotypes at full sunlight, verified that the former is more tolerant to radiation than the Amelonados. Scavina-6 kept more leaves and grew well at full exposition, whereas the leaf area of Amelonado was halved, showing that seedling capacity to grow under full sunlight is also related to genetic factors.

Cacao growth and development, as also occurs with other tropical woody species, is highly dependent on temperature (Raja Harun and Hardwick, 1988b; Hadley et al., 1994). This can be observed through the reduction of photosynthetic rates at temperatures above or below the range considered optimal (Raja Harun and Hardwick, 1988b). Low temperatures affect mainly vegetative growth (Alvim et al., 1977), flowering (Alvim, 1988) and fruit development (Sale, 1969).

Daymond and Hadley (2004), evaluating the effect of temperature on the initial vegetative growth, emission of chl fluorescence and leaf chl content in seedlings of four cacao genotypes, showed the existence of genetic variability in response to temperature stress. In a study by Amorim and Valle (1993) in which gas exchanges were measured on eight-month-old cacao seedlings submitted to different root temperatures $\left(10,20,30\right.$ and $\left.40^{\circ} \mathrm{C}\right)$ it was found that at root temperatures between 20 and $30^{\circ} \mathrm{C}$ the water fluxes and stomatal conductance were greater than at any other soil temperature. Consequently, the resistance to water movement was low and $\mathrm{CO}_{2}$ assimilation rates were higher.

The temperatures below the point at which development ceases (base temperature) were calculated 
by Daymond and Hadley (2004) to vary from 18.6 to $20.8^{\circ} \mathrm{C}$. These values are considerably higher than those obtained by Alvim (1977), who calculated a base temperature of $9^{\circ} \mathrm{C}$ for Catongo, based in its pod growth. The higher base temperatures of Daymond and Hadley (2004) were probably due to the fact that their studies were conducted under conditions of low irradiance, while the studies by Alvim (1977) were carried out under field conditions.

Okali and Owusu (1975) observed that leaf temperatures of unshaded cacao seedlings are higher than the shaded ones, and the transpiration rate is usually at its maximum. The vertical orientation of developing cacao leaves decreases light interception and, thus, leaves can be kept cooler and water loss may be limited in comparison to the mature horizontally positioned leaves (Abo-Hamed et al., 1983). Low chl content and high anthocyanin pigmentation of expanding leaves also contribute to maintain relatively low leaf temperature and, together with the presence of relatively dense hair cover on the leaf surface, may contribute to further decrease transpiration rates (Abo-Hamed et al., 1983).

Flooding is an important barrier for the initial growth and establishment of cacao in places subjected to periodic waterlogging, as occurs in some cacao producing areas in Brazil, Ghana, Nigeria and Ivory Coast, where total rainfall often largely exceeds evapotranspiration, creating hypoxic conditions in the soil (Sena Gomes and Kozlowski, 1986). In the state of Bahia, Brazil, the hypoxic condition is verified after heavy rainfalls in locations with shallow soils, as well as hydromorphic soils and at the margins of rivers after periodic floods. Decreases in growth and in leaf area, stomatal conductance and photosynthetic rates, as well as epinasty and leaf fall and formation of hypertrophic lenticels and adventitious roots in submerged stems have been found during the flooding period, although the extent of these changes is genotype dependent (Rehem, 2006). Sena Gomes and Kozlowski (1986) reported similar results for cacao seedlings of Catongo. Bertolde (2007) studying 35 cacao clones in the young phase found some tolerant genotypes and demonstrated that there are no significant relationships among physiological variables in response to flooding and heterozygosis patterns. In any case, growth inhibitions in plants submitted to soil flooding reduce pod production due to the extension of the period to first flowering and suppression of vegetative growth (Sena Gomes and Kozlowski, 1986), as found by Mariano and Monteiro (1982) who showed a reduction ( $\sim 60 \%)$ in pod production after a flooding of some weeks.

Stomatal opening in cacao leaves is related to the air relative humidity $(\mathrm{RH})$ - stomata are kept more open at higher than lower RH (Sena Gomes et al., 1987). Stomatal closure does not efficiently control water loss probably due to a high cuticular transpiration. Cacao leaves do not show high stomatal resistance under water stress and low RH (Raja Harun and Hardwick, 1988b), but some genotypes with an efficient mechanism of stomatal regulation show a decrease in transpiration under water stress. This may an important acclimation strategy against drought (Balasimha, 1988). In fact, the extreme sensitivity of some cacao genotypes to low RH can be a limiting growth factor in areas where RH is low (Sena Gomes et al., 1987). In such areas, growth would be adversely affected as a result of stomatal closure and, consequently, a reduction of $A$ is to be expected. The inefficient use of water (low water-use efficiency, WUE) at low RH probably would cause water deficit in shoots under conditions of limited soil water supply (Sena Gomes et al., 1987). High $A$ and high WUE of cacao in a high humidity regime are consistent with many species of the humid tropics (Alvim, 1977; Wood, 1985).

Almeida et al. (2002b) evaluated the effects of water stress in 5-month-old seedlings of eight cacao genotypes grafted on the variety Cacau Comum, and verified (i) that drought resistance occurs through osmotic adjustment in most genotypes; (ii) the genotypes maintained values of relative water content at around $90 \%$ with a leaf water potential $\left(\Psi_{\mathrm{w}}\right)$ of approximately -1.0 MPa, gradually reaching $55 \%$ at $-3.5 \mathrm{MPa}$; (iii) a significant increase in leaf concentration of $\mathrm{K}$ and $\mathrm{P}$ during the dehydration process of some genotypes at $\Psi_{\mathrm{w}}$ of $-1.5 \mathrm{MPa}$.

In cacao, leaf export rate of carbon is sharply reduced with the decline of $\Psi_{w}$ between -0.8 and -2.0 MPa, being strictly associated with both $A$ and the export capacity, which is strongly reduced when $A$ approaches zero (Deng et al., 1989). Deng et al. (1990) found values of $A$ close to zero at $\Psi_{\mathrm{w}}$ below -1.6 MPa, while average values of $A$, about $2.2 \mu \mathrm{mol} \mathrm{CO}_{2} \mathrm{~m}^{-2} \mathrm{~s}^{-1}$, were found at $\Psi_{\mathrm{w}}$ between -1.4 and -1.5 MPa. This was also observed by Gama- 
Rodrigues et al. (1995), who attributed to K fertilization, independent of the $\mathrm{K}$ source, a role in the mechanisms of reduction of the negative effects of severe water stress in cacao.

Cacao requires large amounts of $\mathrm{K}$, with around $700 \mathrm{~kg}$ $\mathrm{ha}^{-1}$ being necessary to produce $1000 \mathrm{~kg}$ of seeds per year (Thong and Ng, 1980). This element corresponds to about $70 \%$ of the nutrients in the sap of the cacao xylem (Martins, 1976). Orchard (1978) showed in cacao seedlings that high doses of $\mathrm{K}\left(5 \mathrm{mmol} \mathrm{L}^{-1}\right)$ promoted increases in leaf area without affecting dry biomass production. He also showed that there is an inverse relationship between leaf transpiration and $\mathrm{K}$ doses. Under field conditions cacao trees well supplied with $\mathrm{K}$ may be more tolerant to the adverse effects of water stress (Bosshart and Uexkhull, 1987). According to GamaRodrigues et al. (1995), $\mathrm{KCl}$ was the potassium source that induced the lowest stomatal conductance, transpiration rate and $A$, differing significantly from the sources $\mathrm{K}_{2} \mathrm{SO}_{4}$ and Kalsilite, although there were no significant effects among $\mathrm{K}$ sources on WUE, $\Psi_{w}$ and internal $\mathrm{CO}_{2}$ concentration. The largest dose of $\mathrm{K}$ added to the soil, however, resulted in smaller values of $A$ and larger values of $E$, thus decreasing WUE but without affecting shoot dry biomass.

\section{FINE ROOTS IN CACAO TREES}

The capacity of a tree to absorb water and nutrients depends, among other factors, of fine root dynamics (mortality rates and regrowth of fine roots) as well as its variation in time. The turnover of fine roots can contribute with a significant proportion of recycled nutrients in agroforestry systems, where the competition between forest trees and crops for water and nutrient depends on the temporal pattern of fine root regrowth (Muñoz and Beer, 2001). Studies done under greenhouse conditions have shown that cacao seedlings, as for many tropical woody species, have alternative phases of root and shoot growth (Taylor and Hadley, 1987). The evaluation of fine root growth of cacao trees, studied under field conditions, has been very much limited to static inventory data, for example, assessment of biomass at a given moment in time (Beer et al., 1990). Although Kummerow et al. $(1981,1982)$ accomplished a pioneer study with cacao root dynamics, their methodology involved sequential coring, which can lead to a considerable over or underestimation of root productivity (Anderson and Ingram, 1993).

Biomass of active fine roots ( $\leq 2 \mathrm{~mm}$ at $0-10 \mathrm{~cm}$ depth) of 11-year-old cacao plants shaded by Erythrina glauca was reported as $0.8 \mathrm{Mg} \mathrm{ha}^{-1}$ (Kummerow et al. 1981) and $0.4 \mathrm{Mg} \mathrm{ha}^{-1}$ for roots $\leq 1 \mathrm{~mm}$ (Kummerow et al. 1982). In cacao plantations shaded by E. poeppigiana or Cordia alliodora the biomass of cacao fine roots, on average approximately $1.0 \mathrm{Mg} \mathrm{ha}^{-1}$, changed little during the year (Muñoz and Beer, 2001). The maximum value found at the beginning of the rainy season was $1.85 \mathrm{Mg} \mathrm{ha}^{-1}$ in the cacao-C. alliodora system compared to $1.20 \mathrm{Mg} \mathrm{ha}^{-1}$ for cacao-E. poeppigiana. According to Muñoz and Beer (2001), if the annual turnover of fine roots were constant and close to $1.0 \mathrm{Mg} \mathrm{ha}^{-1}$ in both systems, the input of nutrients would be 23-24 (N), 2 (P), 14-16 (K), 7-11 (Ca) and 3-10 (Mg) kg ha-1 $\mathrm{yr}^{-1}$, representing 6-13\% and 3-6\% of the total input of nutrients in the organic matter for the C. alliodora and E. poeppigiana systems, respectively.

Growth and longevity measurements of fine roots (diameter $<1 \mathrm{~mm}$ ) realized by Silva and Kummerow (1998) directly in the soil-litter interface, in a Brazilian cacao plantation shaded with $E$. fusca, demonstrated that the elongation rates of fine roots were, on average, 3.7 and $1.8 \mathrm{~mm} \mathrm{~d}^{-1}$ for ramifications of first and second order, respectively. They also found that the average period of functional life of these roots was $3 \mathrm{~d}$ within a range of 1 to $10 \mathrm{~d}$, and that growth of fine roots was closely correlated with rain frequency. Data reported by Silva and Kummerow (1998), Kummerow et al. (1982) and Medeiros et al. (1987) suggest that life spans of fine roots are short but, in compensation, they have high turnover rates.

According to Muñoz and Beer (2001), the low fine root production between October and January in Costa Rica is probably the result of internal distribution of carbon for pod production that takes six months to develop and mature, and are harvested in December-January. Furthermore, these authors reported that partial pruning of cacao in December might also reduce cacao fine root production during the following months due to reduction in photoassimilate production and internal competition between flushing and root renewal (Muñoz and Beer, 2001). A negative correlation between number of new leaves per flush and number of growing root tips was reported by Kummerow et al. (1982). The observations of 
Muñoz and Beer (2001) in Costa Rica are consistent with observations found in Brazil in that the number of active cacao root tips (0-10 cm of soil depth) was lower in the driest month and higher in the wettest month (Kummerow et al., 1982). Therefore, this temporary increase in fine root production seems to be part of the normal phenological cycle of cacao (Muñoz and Beer, 2001) since formation of new root tips in cacao grown in nutrient solution was reported only during the rainy month of July in Costa Rica (Rodriguez et al., 1963). Additionally, the results regarding fine root dynamics of shaded cacao plantations suggest that a greater proportion of nutrients in organic or inorganic fertilizers is absorbed by cacao at the beginning rather than at the end of the rainy season (Muñoz and Beer, 2001).

Unpublished results of an experiment conducted in a semi-arid region of Bahia, Brazil, in which irrigation was performed by placing one or two plastic pipes at $0.30 \mathrm{~m}$ from the trunk with drip emitters $0.50 \mathrm{~m}$ apart revealed that in 35-month-old cacao plants grown in plots with two irrigation pipes, the longitudinal root length (along the planting line) was about $1.70 \mathrm{~m}$ and the perpendicular (to the planting line) root length was about $1.0 \mathrm{~m}$ for both sides of the trunk. For the cacao plots with only one pipe the longitudinal root length (along the planting line) was, on average, $2.0 \mathrm{~m}$. Perpendicularly to the planting line a clear root displacement towards the dripping pipe was observed. At the opposite side, without a pipe, the roots were finer, fewer and smaller in length. Clearly, the greater concentration of radicels was observed near the irrigation pipe (B.V. Leite, 2007; unpublished results).

In the two-pipe plots the pivotal roots reached a depth of $1.3 \mathrm{~m}$ against $1.0 \mathrm{~m}$ for the one pipe irrigation plot, indicating that the growth limitation was due to the size of the wetted soil area. The wetted area, after $2 \mathrm{~h}$ of irrigation, reached $0.7 \mathrm{~m}$ in depth and $0.6 \mathrm{~m}$ wide. In this system $80 \%$ of the roots were concentrated between 0.1 to $0.6 \mathrm{~m}$, 3\% between $0-0.1 \mathrm{~m}$ and $17 \%$ below $0.6 \mathrm{~m}$ depth. For the one-pipe plot the wetted area was $0.4 \mathrm{~m}$ in depth and $0.5 \mathrm{~m}$ wide after $2 \mathrm{~h}$ of irrigation. In this system $56 \%$ of the roots were distributed between $0.1-0.4 \mathrm{~m}, 9 \%$ in the range $0-0.1 \mathrm{~m}$ and $35 \%$ below $0.5 \mathrm{~m}$ depth skewed to the side of the irrigation pipe. The distribution of fine, medium and coarse roots followed the same patterns, that is, in the two-pipe plots they were distributed along the two sides of the pipes. The fine roots were at a higher percentage while the medium and coarse roots presented about the same percentage. In the one-pipe plots the percentage of fine roots were higher than medium and coarse roots, however low in number and also distributed on the side of the irrigation pipe (B.V. Leite, 2007, unpublished results). From these preliminary results it can be concluded that the behavior of the plant as a whole, and the root system in particular, is different from the traditional cropping areas in which irrigation depends on rainfall. In the traditional areas the root system is almost all concentrated in the first $0.2 \mathrm{~m}$ soil layer with most of the fine roots in the first $0.10 \mathrm{~m}$ (Leite and Cadima Zevallos, 1991).

\section{THE FLUSHING CYCLE}

Formation of a cacao branch is characterized by alternate periods of growth and quiescence denominated the flush cycle (Greathouse et al., 1971). During flush activity a variable number of leaves is produced in fast succession, which expand very quickly (Baker and Hardwick, 1973). As mentioned earlier, leaves, along the expansion stage, are pale green and sometimes pink colored due to presence of anthocyanins (Orchard et al., 1980). Even completely expanded they do not turn dark green, because they synthesize chl very slowly during expansion. Although illuminated, the greater synthesis of chl only occurs after the leaves reach their maximum expansion (Abo-Hamed et al., 1981). This model of chl development is uncommon compared to what happens during leaf development in a typical plant of temperate climate, in which chl concentration per unit area usually reaches a maximum before the leaf is totally expanded (Baker and Hardwick, 1973).

Usually under field conditions the flushing cycle is activated by environmental changes (Almeida et al., 1987). However, the cycle persists under constant conditions (Orchard et al., 1980), indicating that along the flush cycle there is an endogenous form of control. Studies reported by Alvim et al. (1974b), Orchard et al. (1981) and Abo-Hamed et al. (1981) showed that the alternancy of growth and quiescence periods of the apical bud of the cacao branch (the flush cycle) is controlled by a regular cycle of accumulation and depletion of growth promoter and inhibitor compounds in the bud. Instead of in situ synthesis, it was suggested 
that transport of abscisic acid (ABA) (Alvim et al., 1974b) and cytokinins (Orchard et al., 1981) occurs to the apical bud.

Orchard et al. (1981) showed that the highest levels of auxin and cytokinin are found in young, expanding cacao leaves of a new flush. This suggests that these leaves could be acting as sinks, importing auxin and cytokinins from other parts of the plant, or as auxin and cytokinin sources from where these promoters are exported to the apical bud and other plant parts. The auxin and cytokinin levels in young leaves close to the apex could also reflect the increase in transport of these compounds to the higher parts of the flush, including the apex (Abo-Hamed et al., 1984).

Analyses of new (NF) and previous flushes (PF) of cacao plants under controlled environment (Orchard et al., 1980) or under water stress conditions (Alvim et al., 1974b) showed high leaf levels of ABA when the apex is in the quiescence phase of the cycle. In agreement with the distribution of $\left[{ }^{14} \mathrm{C}\right] \mathrm{ABA}$ in cacao, it is suggested that ABA is exported from the leaf, via phloem, to areas of low ABA concentrations such as buds and young leaves, consistent with source/sink relationships. ABA induces branch quiescence or alternatively helps to maintain the branch in the non-active state. Appearance of radioactivity in mature leaves can be due to the lateral movement of $\left[{ }^{14} \mathrm{C}\right] \mathrm{ABA}$ in the xylem due to transpiration flow (Abo-Hamed et al., 1981).

Cacao seedlings under optimal irrigation conditions also show flush growth, which is related with changes in the flush ABA levels (Orchard et al., 1980). These observations suggest that despite of an adequate water supply, the seedlings suffer from an internal water deficit when the water uptake rate by the root system is lower than the rate of losses by leaf transpiration. This would cause the accumulation of ABA in the apex and, consequently, the imposition of apical bud inactivity at least in part of the interflush period. This hypothesis was confirmed by Abo-Hamed et al. (1983) after relating physical parameters (leaf blade position, population of hairs, cuticle thickness and number of stomata) of leaves of a new flush with transpiration and, therefore, with the water balance of cocoa seedlings in different stages of the flush cycle.

The decrease in diffusive resistance and increase of water loss at the I-1 stage coincide with the period of higher ABA levels in leaves of the new as well as previous older flushes (Orchard et al., 1980). This formation of ABA after stage F-2 could be the result of water stress created by leaf transpiration exceeding the capacity of water uptake. The rate of maximum water loss of a new flush is only reached when the leaves are totally expanded, stomata completely developed and the leaves horizontally positioned (Abo-Hamed et al., 1983).

Iserentant (1976), comparing the effects of removal of all leaves of cacao seedlings in stages equivalent to F-1 and I-2 of the flushing cycle, verified the break of apical dormancy after the defoliation in both stages and concluded that quiescence in seedlings was due to correlative inhibition instead of a true dormancy. Similar results were found by Abo-Hamed et al. (1981) when only leaves in stages F-2 and I-2 of a NF were removed. This suggests that there are no reversibility or irreversibility stages in cacao seedlings (Abo-Hamed et al., 1981), as described by Vogel (1975) for cacao trees grown under field conditions. However, even in plantlets, it seems that two physiological stages exist in the period of bud growth inhibition (Abo-Hamed et al., 1981).

The initial phase of quiescence was described by Vogel (1975) as a reversible phase that occurs during F-2 (Abo-Hamed et al., 1981). It appears that this phase in cacao seedlings can be initiated by the competition for nutrients between the apex and the developing leaves of the flush. According to Orchard et al. (1980), F-2 leaves of a new flush contain low levels of ABA and, consequently, are not the source of this compound. Since the removal of leaves in the flush stimulates the apical bud to produce new leaves, this stimulus could result in the removal of a powerful drain for nutrients instead of the removal of an ABA source (Abo-Hamed et al., 1981). Only the second phase, previously known as the irreversible phase (dormancy in I-1 and I-2), is controlled by the transport of ABA from mature leaves to the apex. In this case, the role of ABA seems to be in maintaining rather than initiating apical bud quiescence (Abo-Hamed et al., 1981).

Removal of NF leaves at the I-2 stage causes reduction in the quiescence period of the apex (AboHamed et al., 1981). Since in this period the NF leaves contain high ABA levels (Orchard et al., 1980), probably the inhibitory effect of NF leaves in I-2 is due to ABA and its transport to the apex (Abo-Hamed et al., 1981). The removal of PF leaves at the I-1 stage also promotes 
reduction in the apex dormancy period. These mature leaves are sinks for nutrients (Abo-Hamed et al., 1981) and also contain high ABA levels (Orchard et al., 1980), therefore, they could serve as an ABA source for the apex, like mature leaves of NF (Abo-Hamed et al., 1981).

Application of ABA always extends the inactive period. Alternatively, the application of growth promoters $\left(\mathrm{GA}_{3}\right.$ or zeatin) reduces the duration of the subsequent quiescence stage of the apex. Probably, the effects of growth promoters in the reduction of the quiescence period are overcome by the endogenous inhibitors in the leaves. The fact that $\mathrm{GA}_{3}$ applied to NF leaves in the F-2 stage does not promote a reduction effect on the duration of the apex dormancy period reinforces the hypothesis that the apical dominance, at this stage, is due to competition by nutrients instead of the presence of hormonal inhibitors in the leaves (AboHamed et al., 1981).

Developing leaves display a lower photosynthetic capacity (Baker and Hardwick, 1973), which turn them into sinks for photoassimilates during most of this phase. During this period, leaf levels of fructose, glucose and sucrose increase, presumably due to imports from older leaves. However, when leaf expansion ends, the glucose and fructose levels decline and sucrose concentration increases, reflecting the end of photoassimilate import and the beginning of endogenous sucrose synthesis (Baker and Hardwick, 1975). The simultaneous development of several leaves within a flush constitutes, however, a very large carbohydrate consumption event during a period of 10 to $15 \mathrm{~d}$ that exceeds the available current photosynthate (Machado and Hardwick, 1988). Leaves that develop at the end of a normal flush, although without large competitive influence from other leaves in development within the flush, are smaller in size (Machado and Hardwick, 1987). This strongly suggests that the subsequent leaves in a normal flush grow under the deficit of a presumable factor that supports growth, such as carbohydrate, arresting, therefore, the potential for full size growth (Machado and Hardwick, 1988). In the interflush the stock of carbohydrates is reestablished and, with the return of a favorable balance, the appearance of a new flush can occur (Machado and Hardwick, 1988).

F-2 leaves of a NF represent, however, a powerful sink for nutrients, which would be in competition with the shoot meristem (Abo-Hamed et al., 1981). Chemical composition of mature cacao leaves showed significant decrease in total $\mathrm{N}$ levels during the development of a new flush (Santana and Igue, 1979). This decline was attributed to an increase in $\mathrm{N}$ mobilization to expanding leaves. At this stage, there is a large quantity of endogenous auxin (Orchard et al., 1981) and a high rate of ${ }^{14} \mathrm{C}$ translocated out of the labeled leaf as compared with other stages (Sleigh, 1981). Additionally, at the beginning of F-2 the amount of carbohydrate translocated from mature leaves to the developing flush exceeds (positive balance) that required for leaf growth. This excess can be stored in the top branches and used for its growth, mainly in mid F-2, when the leaves of the flush constitute a very strong drainage for carbohydrate and the amount required for leaf growth increases considerably (Machado and Hardwick, 1988).

In the I-2 stage, NF leaves are completely expanded and show maximum photosynthetic capacity and, therefore, capable of photoassimilate export (Baker and Hardwick, 1975). At the end of this stage, cytokinin, imported from the root, accumulates in the apical bud and helps activating the break of bud quiescence in the transition to stage F-1 (Alvim et al., 1974b; Orchard et al., 1981). Observations reported by Sleigh (1981) and later confirmed by Machado (1986) showed that a considerable percentage of ${ }^{14} \mathrm{C}$ assimilated by mature leaves is imported by leaves in expansion at the $\mathrm{F}-2$ stage. If a high proportion of photoassimilates is removed from mature leaves during the F-2 stage, a corresponding increase of photosynthesis would be expected, which is not the case. This clearly demonstrates that the requirement of carbon for growth, at least for leaves, does not directly control photosynthesis of mature cacao leaves (Machado and Hardwick, 1988). According to Baker and Hardwick (1973), photosynthetic rates of older leaves, with $90 \%$ more chl, are only $10-20 \%$ higher than that of leaves at the end of flushing. Consequently, the photosynthetic efficiency of older leaves is significantly smaller. Therefore, in leaves of cacao the decline in photosynthetic efficiency occurs during the period between the end of flushing and onset of senescence.

Information exists about the periodicity of cacao leaf production in relation to changes of climatic elements, especially the effect of temperature (Couprie, 1972), solar radiation (Snoeck, 1979) and rainfall (Alvim and Alvim, 
1978). Almeida et al. (1987), in a study carried out in Ilhéus, Bahia state, Brazil, of the relationship between actual evapotranspiration (ET) and reference evapotranspiration (ETR) to quantify the effects of water deficit on cacao flushing, included the relationship ET/ ETR in the original expression of degree-day in order to evaluate the concomitant effects of temperature and water on flushing. Nominating this weighted function penalized degree-days (PDD), they verified that this function presented a correlation of around $80 \%$ of the existing interactions between flushing and weather factors. The high degree of significance of this function is due to the fact that PDD represents the joint effects of energy and water. For the conditions of Bahia the PDD that better explained flushing was the one calculated three weeks before leaf emission. In Bahia, the main flushing period is from September to February, with alternation of short periods of vegetative rest; along those months, the energy curve (averages day ${ }^{-1}$ ) is in ascension and coincides with the period of more intense flushing (Almeida et al., 1987). Furthermore, in that area the mean air temperature at the eighth week, and solar radiation and insolation of the ninth week exert great influence on flushing, while the period of decreasing energy (solar radiation, temperature and PDD) coincides with the months in which no flushing occurs (Almeida et al., 1987).

The seasonal influence of temperature on phenological events is evident in the flowering, fruiting and pod growth profiles found by Cazorla et al. (1989), who also observed low flushing during June to September. This period is characterized by relatively low temperatures. Therefore, the absence of flushing and flowering in south Bahia is intimately related to the decrease of fruiting, culminating with an almost total absence of pods in January to March of the following year (Leite and Valle, 2000). In Bahia, cacao usually stops flushing from March to July, remaining in a relative vegetative rest afterwards (Alvim, 1977), therefore, the period of minimum flushing varies from 90 to $120 \mathrm{~d}$ - June to September (Alvim et al., 1974a).

Alvim et al. (1974a), Alvim (1977) and Almeida et al. (1987) studied the influence of rainfall and water balance on flushing within defined months of the year. According to Alvim (1977), in most cacao producing areas leaf emission begins following the first rains after a dry period. For Sale (1968) rainfall or irrigation, after a dry period, is a necessary condition to elicit flushing. However, under field conditions, flushing begins in response to an increase of plant $\Psi_{\mathrm{w}}$ and not necessarily to rain, after a period of humidity stress (Almeida et al., 1987). Once growth of the apical bud is resumed, rain plays a decisive effect on leaf expansion, this being one of the possible reasons to explain the vigorous flushing associated with rain occurrence following a period of humidity stress (Alvim, 1977).

Almeida et al. (1987) showed that during the vegetative inactive period, the changes in soil water levels and, consequently, the sequence of water deficits and excesses do not seem to play a role, at least directly, in the phenomenon of bud dormancy break. However, once the apical bud dormancy is broken, water availability seems to exert great influence on the intensity of leaf emission. Therefore, flushing becomes relatively intense when the period of water deficit (storage of water in the soil $<50 \mathrm{~mm}$ ) is followed by rains, that is, replenishment of soil water content (Almeida et al., 1987). These results corroborated those found by Sale (1968), Alvim (1977) and Machado and Alvim (1981).

Physiological responses of cacao are affected when the soil water content is below $60-70 \%$ of the maximum available soil water capacity (Alvim, 1960). Therefore, the development of water deficit during the dry season is considered an important factor in the control of the pattern of flush growth of field grown cacao plants (Alvim et al., 1974a). Transition from inactivity to apical growth of a branch at the beginning of a new flush cycle occurs following the decrease of water deficit, through leaf shedding or beginning of the rainy season, with the consequent reduction of the high levels of ABA produced by the shoots in the precedent period of water deficit (Alvim et al., 1974b). On the other hand, the effects triggered by dry periods followed by rain on the apical bud activity seem to occur through modifications of the ABA:cytokinins balance, that is, flushing is inhibited by the increase in that relationship (Alvim et al., 1974b). Removal of mature leaves produces modifications in that balance; therefore, after defoliation, ABA level in the apical bud decreases, while cytokinins content increases considerably (Alvim and Alvim, 1976).

In tropical climates, where temperature oscillations are relatively small compared to temperate climates, trees 
grow intermittently within seasonal climatic sequences and flushing is considered the beginning of a growth cycle (Alvim, 1977). For cacao grown in southeastern Bahia the flowering, fruiting and pod growth patterns show low flushing in June to September (Cazorla et al., 1989), a period characterized by relatively lower temperatures (Leite and Valle, 2000). According to Almeida et al. (1987), temperatures above a reference value (around $23^{\circ} \mathrm{C}$ ) coincide with periods of increased flushing. Similar responses were observed under controlled conditions by Sale (1968), when cacao plants submitted to $23.3,26.6$ and $30^{\circ} \mathrm{C}$ emitted leaves respectively at 95, 36 and $20 \mathrm{~d}$. Therefore, it seems that high temperatures accelerate flushing initiation.

\section{ROLE OF ENDOGENOUS FACTORS ON CACAO FLOWERING}

Cacao produces caulescent flowers in meristematic tissues located above leaf scars in the woody stem of plants of two- or more years old. The floral meristem or cushion produces flowers over the tree's life span (Aneja et al., 1999). These flowers contain different polyphenolic compounds such as: (i) hydroxycinnamic acids, located in the periphery of the organs, except in the ovary where parenchyma cells are present and ovules occur, and (ii) tannins and anthocyanins, both located in the epidermis of different floral parts. Anthocyanins are mainly restricted to ornamentation in petals and staminoids (Alemanno et al., 2003). These external locations of phenolic compounds can work as a chemical protective barrier against damages promoted by environmental factors (Alemanno et al., 2003).

In each flower, the sepals begin to dehisce in late afternoon, and the flower is completely open at the beginning of the following morning, a period in which the anthers liberate pollen and the stigma is receptive (Aneja et al., 1999). Although hermaphrodite, cacao flowers have anthers covered by petals and, without the intervention of insects, mainly Forcipomyia sp (Diptera: Ceratopogonidae), pollination would be impaired since the viscous pollen does not come into contact with the stigma spontaneously (Dias et al., 1997). In Bahia high populations of this insect are found during March to July increasing the pollination of the main harvest (safra). During the high temperature months the fly populations are low, which is reflected in the low productivity of sporadic harvests in that region (K. Nakayama, 2007; unpublished results). On the other hand, if the flowers are not pollinated, they abscise 24-36 h after anthesis, without visible signals of senescence (Aneja et al., 1999; Hasenstein and Zavada, 2001). If pollination is accomplished and fertilization occurs, the ovary increases in size, the pedicel enlarges and the corolla wilts and deteriorates (Aneja et al., 1999).

The genus Theobroma represents an atypical example of an ovarian auto-incompatibility system, quite different from most vegetal incompatibility systems in nature (de Nettancourt, 1977). Incompatibility in cacao was first reported by Pound (1932), who verified the occurrence of changes from self-incompatibility to self-compatibility during certain periods of the year. According to Lanaud et al. (1987) the incompatibility system in cacao is not simple, since it includes different degrees of incompatibility. Also, these authors reported a high level of autopollination in auto-incompatible trees of some genotypes.

Although there is no causal link between expression of enzymatic activity and incompatibility, Warren and Sunnita (1995) verified that enzymes like isocitrate dehydrogenase, malate dehydrogenase and acid phosphatase are indicative of incompatibility systems (IS). In contrast, Aneja et al. (1992, 1994) showed that the pollen grains of the auto-incompatible clone IMC-30 did not germinate at low $\mathrm{CO}_{2}$ partial pressure; high $\mathrm{CO}_{2}$ concentration, however, could overcome IS in selfpollinated flowers. Therefore, the main effect of overcoming IS in autoincompatible genotypes occurs when (self) incompatible and compatible (foreign) pollen are mixed permitting autopollination in autoincompatible trees (Glendinning, 1960; Bartley, 1969; Lanaud et al. 1987), implying that in Theobroma some substance other than $\mathrm{CO}_{2}$ may condition the maternal plant autopollination (Hasenstein and Zavada, 2001).

The percentage of flowers that set pods in cacao is usually very low, i.e. 0.5 - 5\% (Aneja et al., 1999). This is partly due to the fact that the effective rate of autopollination in auto-incompatible trees is low, while in autocompatible trees it can reach up to $43 \%$ (Yamada and Guries, 1998). The quality of pollination can depend on two factors, the degree of pollen compatibility and the number of pollen grains deposited on the stigma (Lanaud 
et al., 1987). There is some evidence that a high number of pollen grains is beneficial for overall pod set (Hasenstein and Zavada, 2001) and that a high proportion of pollinations results from the visit of a single pollinator (Yamada and Guries, 1998). At anthesis the auxin concentration is low and the retention of flowers, as well as fertilization and possibly pod development, depend on an external source or signal for satisfactory pollination or pollen growth, as found by Hasenstein and Zavada (2001). They also noted an inverse correlation between the number of flowers per plant and the auxin content, suggesting that the genetic control of autoincompatibility in cacao can be modulated by the hormonal content of the flower and this could explain the great number of pods observed even after incompatible pollinations.

A better understanding of the factors involved in floral abscission can be of great horticultural value (Aneja et al., 1999). Abscission of flowers in cacao occurs within 2-3 d after anthesis in the absence of pollination and fertilization, and even after manual pollination, only a small number of flowers develops and produces pods (Hasenstein and Zavada, 2001). Although there is no recognizable abscission area in the flower pedicel at anthesis, within $24 \mathrm{~h}$ starch grains appear in the pedicel cortex, in the neighborhood of the incipient abscission area, and cell separation begins in the epidermis at 2-3 mm from the point of pedicel attachment to the tree trunk (Aneja et al., 1999). Flower abscission due to pollination begins well before the pollinic tube reaches the ovules (Aneja et al., 1994); Baker et al., 1997).

It has been observed that auxin concentration of developing buds is high and depends on the number of flowers formed; however, when the buds mature, the auxin level decreases allowing the initiation of the abscission process (Hasenstein and Zavada, 2001). In contrast, ABA levels of the flower increase significantly before abscission, while most of the increase in ethylene production occurs simultaneously with abscission (Aneja et al., 1999). There is no abscission in the absence of ABA in spite of the presence of ethylene. Therefore, in cacao flowers, ABA seems to be the primary inductor of abscission, while ethylene, although accelerating abscission does not seem to be required for the process (Aneja et al., 1999). The increase of indoleacetic acid (IAA) levels in the cacao ovary as a result of pollination and fertilization (Baker et al., 1997) or application of naphthalene acetic acid can overcome the effect of ABA in the formation of the abscission area (Aneja et al., 1999).

Work by Baker et al. (1997) with hormonal changes after compatible and incompatible pollination indicate a strong increase of endogenous auxin after compatible pollination and a strong increase of ethylene after incompatible pollination. These hormonal responses occur before the interaction pollinic tube-ovule suggesting the existence of an incompatibility system influenced by auxin (Hasenstein and Zavada, 2001). According to Aneja et al. (1994), the ability of $\mathrm{CO}_{2}$ to overcome abscission and the subsequent autocompatibility can be the result of minimization of ethylene effects. However, it is conceivable that high auxin levels also override the abscission signal, affecting or controlling the auto-incompatibility response in Theobroma (Hasenstein and Zavada, 2001).

Since flower production represents a considerable plant investment (Valle et al., 1990), the number of flowers can affect the auxin partition to each flower. According to Hasenstein and Zavada (2001), this would explain the low concentration of endogenous auxin in clones with high flower productions (high-flower producers). Auxin concentration is significantly higher in clones with low production of flowers (low-flower producers). Producers of a high number of flowers can show a 20-fold improvement in pod development compared to natural pod retention, in spite of the existence of a poor relationship between pods and flowers. Besides, there is a strong negative correlation between the number of flowers produced and the endogenous content of IAA, while the content of ABA did not differ between the two sets (Hasenstein and Zavada, 2001).

\section{EFFECTS OF ABIOTIC FACTORS ON YIELD}

The adult stage of cacao is reached when the tree enters reproductive growth. Pod production is small during the first years and increases every year as the tree gets older. Studying the yield of cacao per tree, Bartley (1970) proposed to initiate selection of potentially highyielding cacao trees in the eighth year of planting, since with young trees fructification begins approximately at the fourth year. Only at the eighth or 10th year after 
planting do the trees express their productivity potential (Dias and Kageyama, 1997). Also, measurements of diameter and stem height, average crown diameter and leaf area of cacao trees between one to three years old have been used as variables to estimate the yield capacity of cacao (Batista and Alvim, 1981; Garcia and Nicolella, 1985). However, the same abiotic stresses that reduce pod production can also indirectly decrease yield by increasing the duration of the juvenile period, which varies widely within cacao genotypes. Flowering, for instance, in some cacao hybrids can begin 18 months after planting in the field, while in other genotypes it might be initiated after three to five years (Sena Gomes and Kozlowski, 1986).

The most important determinant parameters of cacao yield are related to (i) light interception, photosynthesis and capacity of distributing photoassimilate, (ii) maintenance respiration and (iii) pod morphology and seed fermentation (Zuidema et al., 2005). Comprehensibly, these three items are crucial to seed yield and were examined in initial studies concerning cacao production (Yapp and Hadley, 1994). On the other hand, these parameters can be modified by abiotic factors, such as those inhibiting, for instance, initiation of floral buds (Alvim, 1977) or those that, after flowering and pod set, influence the pod development (Wood, 1985). Climatic changes exert outstanding effects in the flush cycle, an important determinant factor of yield (Almeida et al., 1987).

In the definition of an appropriate climate for cacao cultivation in forest understorey conditions, it is well known that their microclimatic variables are completely different from the standard weather conditions outside that environment (Bonaparte and Ampofo, 1977). Also, there are indications that the structure and dynamics of the cacao agroecosystem exert some influence in the microclimate (Beer, 1987). Air temperature, RH and rainfall are correlated and affect the seasonality of microclimatic conditions inside a cacao plantation (Miranda et al., 1994). The magnitude of the meteorological parameters varies less in a hot week than in a cooler week. The predominantly clear summer (average of 9 h daily sunshine) and the cloudy winter (average of $5 \mathrm{~h}$ daily sunshine) regulate, to a great extent, the behavior of microclimatic parameters above and inside a cacao plantation.
According to Daymond and Hadley (2004), temperature is one of the main limiting factors for cacao production, since temperature stress affects the seasonal variation in seed yield. In a cacao plantation, the difference in temperature measured outside and inside canopy layers was around $2 \pm 0.5^{\circ} \mathrm{C}$, although higher values have been registered during summer weeks. The undercanopy maximum temperatures are characterized by drops varying from 1 to $3^{\circ} \mathrm{C}$ and temperature differences inside the canopy vary from 2.5 to $4^{\circ} \mathrm{C}$, while the above canopy maximum temperature decreased from 1.5 to $3.5^{\circ} \mathrm{C}$ (Miranda et al., 1994). When measuring leaf temperature in the upper canopy layer of a non-shaded cacao tree on a sunny day, Valle et al. (1987) verified that it was always $2^{\circ} \mathrm{C}$ above the leaf temperatures of the middle and lower canopy layers. Leaves of the upper canopy layer showed higher differences between leaf and air temperature and, therefore, water vapor deficit, in comparison to lower layers.

In its natural habitat wild cacao grows under shade trees, but with a low pod production (Murray and Nichols, 1966) since the shade trees compete with cacao for water, nutrients and light (Bonaparte, 1975). On the other hand, this habitat led people to believe that shade is indispensable for cacao cultivation (Owusu, 1978). Cacao has been, however, traditionally grown under shade regardless of yield (Urquhart, 1961). Evans and Murray (1953) in Trinidad, Alvim (1959) in Costa Rica and Cunningham and Lamb (1959) in Ghana were the pioneers to critically examine the role of shade and light in cacao cultivation. In a shade and manurial experiment in Ghana strong reductions in yield were observed due to shading (Ahenkorah et al., 1974). In fact, cacao grown at full sunlight produced more pods than when grown under shade (Owusu, 1978). It was suggested earlier, with regard to the fundamental points of cultural practices, that the control of both growth and density of cacao trees, as well as the increase in aeration and light penetration are necessary to promote increments in seed production (Vernon and Sunderam, 1972). Nowadays the comprehensive work of Ahenkorah et al. (1987) sheds light on the importance of appropriate fertilization in unshaded cacao plantations.

The cacao leaf is saturated at low irradiance and shows low $A\left(4 \mu \mathrm{mol} \mathrm{CO} \mathrm{Cm}^{-2} \mathrm{~s}^{-1}\right)$ at water vapor deficits between leaf and air of $1.8 \mathrm{kPa}$ (Mielke et al., 2005). 
According to Galyuon et al. (1996) the photosynthetic rate decreases if the photosynthetic apparatus is exposed to $1800 \mu \mathrm{mol} \mathrm{m}^{-2} \mathrm{~s}^{-1}$. Furthermore, extended exposition to high light intensities damages the leaf photosynthetic mechanism (Raja Harun and Hardwick, 1988a). On the other hand, light intensities lower that $1800 \mathrm{~h} \mathrm{yr}^{-1}$ suppress flower production with a considerable depressive effect on pod yield (Asomaning et al., 1971).

Studies on light interception and photosynthesis show that seed production is light limited, probably due to external and internal shade (self-shading) in the cacao stand and light extinction inside the canopy (Yapp and Hadley, 1994). Heavy shade not only reduces seed yield (Zuidema et al., 2005), because of low photosynthate production (Alvim, 1977; Ng, 1982), but also increases the incidence of diseases (Alvim, 1977). On the other hand, cacao is a shade tolerant species (Guers, 1985), in which appropriate shading could lead to adequate photosynthetic rates, growth and seed yield. Shading also helps to reduce effects of unfavorable ecological factors, such as low soil fertility, wind velocity and excessive evapotranspiration (Miyaji et al., 1997a). Furthermore, the forest trees used for shade greatly contribute with the formation of soil organic matter, carbon sequestration, nutrient recycling and maintenance of biodiversity (Müller and Gama Rodrigues, 2007; Lobão et al., 2007). Specifically in regions with low access to inorganic fertilizers, the multistrata plantation is used to maintain soil fertility with the subsequent increase in nutrient availability for cacao (Isaac et al., 2007). Forest trees for shading also reduce wind speed and evapotranspiration (Beer et al., 1998), consequently, decrease humidity stresses and extreme air and soil temperatures during the dry season (AnimKwapong, 2003). This is essential for the survival and the establishment of cacao seedlings in dry and seasonally humid environments (Beer, 1987) since they are highly susceptible to dehydration (Leite et al., 1980).

When nutrient availability is not a growth limiting factor, there is a positive correlation between cacao yields and light, as shown by Bonaparte (1975) and Ahenkorah et al. (1987). Vernon (1967) concluded that the relationship between cacao yield and available light was approximately linear from 30 to $60 \%$ full sunlight. However, when modeled from 0 to $100 \%$, a quadratic model showed better adjustment than the simple linear model, suggesting that some degree of shading is desirable.

The higher production of non-shaded cacao implies in a smaller productive lifespan, a larger demand for fertilizers (Owusu, 1978), a decrease in the incidence of cherelle wilt (Asomaning et al., 1971) and larger investments (Ahenkorah et al., 1987). The subsequent decline in productivity (Bonaparte, 1973) is attributed to high losses of exchangeable bases in the soil, attack of insects and diseases, excessive leaf transpiration and increase of soil evaporation (Ahenkorah et al., 1974). The inherent high risk of unshaded cacao cultivation was illustrated by the economical analyses of Cunningham (1963), the extra expenditure and work associated with clear-felling and growing unshaded cacao with great amounts of fertilizers would probably be justifiable only if yields of more than three tons are obtained. However, most of the cacao experiments involving shade and fertilizers show that shade reduces the responses to fertilizer applications (Alvim, 1977) and such conditions are rarely economically justifiable (Beer, 1987). This shows that cacao production is positively related to light intensity (Vernon, 1967), but this relationship depends primarily on the availability of nutrients in the soil.

In commercial plantations it is hard to understand and detail the potential productivity in relation to pod-set and yield, since the cacao canopies are under several shade levels (Alvim, 1977). With shade management practices cacao production can increase during the first decade and thereafter stabilizes (Rosenberg and Marcotte, 2005). Cacao trees can produce during 30 to 80 years (Stevenson, 1987), however, yield decreases subsequently (Rosenberg and Marcotte, 2005). Furthermore, it is probable that the physiology of trees under heavy shade would be modified, because shaded trees can be more efficient in photosynthesis and leaf dynamics, as for example, the increase in leaf lifespan (Miyaji et al., 1997a). According to Owusu (1978), there is a close relationship between these physiological processes and carbohydrates in cacao. Improved growth, increase of flushing, enhanced flowering and increased yield under unshaded or fully exposed conditions can, however, be explained in terms of increase in carbohydrate production (Asomaning et al., 1971). This is exemplified by the internal competition between flowers and pods (Alvim, 1954), in spite of the small total energy 
expenditure for flowering (Valle et al., 1990). Furthermore, Alvim (1977) considers that besides the competition within pods, the annual variation of pod set is subjected also to competition with other vegetative events, such as flushing and root and cambium growth.

Several factors influence leaf dynamics (rates of production and abscission), among them water and light availability, which largely vary between locations and cropping systems (Zuidema et al., 2005). Additionally, wind conditions during the dry season reduce cacao yield due to water loss and reduction of leaf area (Alvim, 1977; Leite et al., 1980). The relative light intensity received by cacao trees cultivated in Southeastern Bahia, a region with an average annual temperature of $23.5^{\circ} \mathrm{C}$, annual total rainfall of approximately $1700 \mathrm{~mm}$, no pronounced dry season and shaded with E. fusca and/or E. poeppigiana, varies between 30 and $100 \%$ of full sunlight and 4 to $10 \%$ radiation at soil level. The average leaf area index and the extinction coefficient are about 3.9 and 0.61, respectively (Miyaji et al., 1997a). Leaf longevity varies with position inside the canopy and/or incident irradiance, time of emergence and height in relation to the soil level. According to Miyaji et al. (1997b) for Catongo trees of about seven years old the leaf duration at heights greater than $220 \mathrm{~cm}$ and above $60 \%$ full sunlight is $181 \mathrm{~d}$, which is half the duration of leaves at heights between $0-150 \mathrm{~cm}$ and 5 to $20 \%$ sunlight. Factors like soil water deficit and leaf respiration, due to high air temperature and high radiation, can be causes for the intensive leaf fall in the middle and upper canopy layers of the cacao crown (Alvim and Alvim, 1978).

The cacao yield is strongly related to rainfall in the dry season. It also depends on soil type and consequently water retention capacity (Zuidema et al., 2005). According to Leite and Cadima Zevallos (1991), the elevation and residence of the water table promote the increase and maintenance of humidity levels above the subsurface of the soil, a zone in which the cacao root system concentrates in traditional cacao cropping areas. To reach high levels of cacao yield in south Bahia, the monthly rainfall totals should be equal or greater than 200 $\mathrm{mm}$, while the permanence of the water table should be more than $30 \mathrm{~d}$ (Leite and Valle, 2000). The fluctuation of the water table can be considered a climatic variable (derived from rainfall) that can influence cacao production as a form of natural sub-irrigation (Leite and
Valle, 2000).

Using a simulation model, Zuidema et al. (2005) showed that annual radiation and rainfall during the dry season explained $70 \%$ of the variations in annual seed yields obtained for 30 sites along the tropical cacao producing areas of the world. Drought promotes decreases in leaf area (Orchard and Saltos, 1988), net carbon assimilation (Hutcheon, 1977), flowering (Sale, 1970) and yield (Khan et al., 1988). Changes and carbon distribution and export will depend on the severity and duration of the stress, as well as its occurrence in relation to flowering, pod set and pod maturation (Deng et al., 1989). There are positive correlations between yield and rainfall during months that precede harvest (Alvim, 1978), where rain distribution is more important than its magnitude (Atanda, 1972). Alvim (1988) considered that harvest can be influenced by the rain distribution that occurred six months before its beginning. This relationship seems valid for countries like Brazil (southeastern Bahia), Ghana, Ivory Costa and Malaysia. In Bahia, the agricultural cacao year comprises April to March and the yield is divided into two distinct periods, temporão (outcrop) from April to August and main crop (safra) from September to March, whose relative importance depends on rain distribution (Alvim, 1973). Furthermore, cacao pods take about six-seven months to complete their development (Almeida and Valle, 1995). This explains the importance of higher rainfall and longer phreatic residence of the water table at the soil subsurface in one year for high production in the following year (Leite and Valle, 2000; Dias and Kageyama, 1997).

According to Valle et al. (1987), data modelled for transpiration showed that on a cloudy day a non-shaded cacao tree could transpire about $45 \mathrm{~L}^{\text {tree }}{ }^{-1}\left(1.2 \mathrm{~L} \mathrm{~m}^{-2} \mathrm{~d}^{-1}\right)$, assuming that all leaves are transpiring at the same rate. $\mathrm{A}$ shaded cacao tree, on the other hand, could transpire about $26 \mathrm{~L}_{\text {tree }}{ }^{-1}\left(0.8 \mathrm{~L} \mathrm{~m}^{-2} \mathrm{~d}^{-1}\right)$. However, on a sunny day both trees showed a substantial difference in transpiration when compared with a cloudy day. The daily transpiration rate was estimated to be $90 \mathrm{~L} \mathrm{tree}^{-1}(2.4$ $\left.\mathrm{L} \mathrm{m}^{-2} \mathrm{~d}^{-1}\right)$ for the unshaded tree and $40 \mathrm{~L}_{\text {tree }}^{-1}\left(1.2 \mathrm{~L} \mathrm{~m}^{-2} \mathrm{~d}^{-1}\right)$ for the shaded one when $100 \%$ of its leaf area was exposed to incident irradiance (Valle et al., 1987). Estimates of daily transpiration on a cloudy day for both tree conditions and for the shaded canopy layers on a 
sunny day were of the same order of magnitude of those calculated by Cadima and Alvim (1983). However, for unshaded trees, on a sunny day, Valle et al. (1987) showed an average transpiration value more than twice the estimated by the latter authors. From the estimated cacao LAI distribution of Miyaji et al. (1997a) and radiation distribution presented by Valle et al. (1987), it is concluded that more than $60 \%$ of the water can be transpired by the upper canopy layers of unshaded trees. In the shaded trees less than $5 \%$ of the absorbed water might be transpired by the upper layers, which is caused by the greater irradiance received in the lower layers than in the top layers due to the shade tree that impedes light penetration to the upper layer even at lower solar angles.

\section{CONCLUDING REMARKS}

The expectation for the next 10 years, without considering India and China, is a consumption increase of nearly one millions tons of cacao seeds. The big question is from where would the extra demand come? A strong possibility is an increase in productivity in West African countries, but this would be at the expense of significant resource inputs and lasting over a long period. Actually, the chocolate industry foresees difficulties about future supplies. Today the world faces a new situation with the search for new renewable energy sources. As an example, Malaysia has replaced cacao plantations with oil palm, and Indonesia has become less and less interested in producing cacao.

According to the World Cocoa Foundation (www. worldcocoafoundation.org) there is a tendency towards an increase in the consumption of chocolate with a high cacao content (43\%) in Europe and USA. Also, there is a world trend in the proliferation of small companies that process cacao and make chocolate. Their search for cacao is remarkable. There is also a consensus that in countries with a better level of development, like Brazil, the future will be the investment in quality and production of differentiated cacao. Therefore, the efforts in Bahia to produce fine cacao is in reality a world tendency for other locations with similar environments, thus, constituting a great opportunity for expansion in this market. Furthermore, the markets under greatest expansion are those of the emerging nations. Therefore, expectations are strong for the inclusion of China and
India in the chocolate consumption market.

However, if the markets show a promising tendency, more and more of the cacao farmers will feel the burden of high costs of resource inputs, mainly for the control of diseases and insects that are steadily increasing. Cacao is attacked by several pests and diseases, with some estimates putting losses as high as 30 to $40 \%$ of global production (www.icco.org/about/pest.aspx). In this sense farmers are seeking for new lands that offer an escape from known diseases, and in this respect we may highlight the importance of studying the behavior of the crop under semi-arid conditions as mentioned earlier. The knowledge of the effects of factors that affect the cacao growth and development under such conditions should even make it possible to engineer new practices for the traditional cropping areas.

Acknowledgements: The senior author gratefully acknowledges the Conselho Nacional de Desenvolvimento Científico e Tecnológico (CNPq), Brazil, for the concession of a fellowship of scientific productivity. Thanks are also in order to Prof. Fábio M. DaMatta, Editor-in-Chief of the Brazilian Journal of Plant Physiology, for the invitation to prepare this review, and to Prof. Raimundo Santos Barros, from the Universidade Federal de Viçosa, for his invaluable suggestions.

\section{REFERENCES}

Abbas BS, Dja'far D (1989) Sensitivity analysis of cacao cultivation: relative profitability of coconut and Leucaena glauca L. (L. leucocephala) as shade plants, based on a case study at Bah Lias Plantation, North Sumatra. Bull. Perkebunnan 20:97-103.

Abo-Hamed S, Collin HA, Hardwick K (1981) Biochemical and physiological aspects of leaf development in cocoa (Theobroma cacao L.). VI. Hormonal interaction between mature leaves and the shoot apex. New Phytol. 89:191-200.

Abo-Hamed S, Collin HA, Hardwick K (1983) Biochemical and physiological aspects of leaf development in cocoa (Theobroma cacao L.). VII. Growth, orientation, surface structure and water loss from developing flush leaves. New Phytol. 95:9-17.

Abo-Hamed S, Collin HA, Hardwick K (1984) Biochemical and physiological aspects of leaf development in 
cocoa (Theobroma cacao L.). VIII. Export and distribution of ${ }^{14} \mathrm{C}$ auxin and cytokinin from the young and mature leaves. New Phytol. 97:219-225.

Ahenkorah Y, Akrofi GS, Adri AK (1974) The end of the first cocoa shade and manurial experiment at the Cocoa Research Institute of Ghana. J. Hort. Sci. 49:43-51.

Ahenkorah Y, Halm BJ, Appiah MR, Akrofi GS, Yirenkyi JEK (1987) Twenty years' results from a shade and fertilizer trial on Amazon cocoa (Theobroma cacao) in Ghana. Exp. Agric. 23:31-39.

Alemanno L, Ramos T, Gargadenec A, Andary C, Ferriere N (2003) Localization and identification of phenolic compounds in Theobroma cacao L. somatic embryogenesis. Ann. Bot. 92:613-623.

Almeida CMVC, Müller MW, Sena-Gomes AR, Matos PGG. (2002a) Sistemas agroflorestais com o cacaueiro como alternativa sustentável para uso em áreas desmatadas, no estado de Rondônia, Brasil. Agrotrópica 14:109-120.

Almeida A-AF, Brito RCT, Aguilar MAG, Valle RR (2002b) Water relations' aspects of Theobroma cacao L. clones. Agrotrópica 14:35-44.

Almeida A-AF, Valle RR (1995) Análise de crescimento do fruto e das sementes de sete genótipos de Theobroma cacao L. Pesq. Agropec. Bras. 30:909-916.

Almeida HA, Machado RCR, Villa Nova NA, Silva WS (1987) Influência de elementos meteorológicos no lançamento foliar do cacaueiro. Rev. Theobroma 17:163-174.

Alverson WS, Whitlock BA, Nyffeler R, Bayer C, Baum DA (1999) Phylogeny of the core Malvales: evidence from ndhF sequence data. Am. J. Bot. 86:1474-1486.

Alvim PT (1954) Studies on the cause of cherelle wilt of cacao. Turrialba 4: 72-78.

Alvim PT (1959) El problema del sombreamiento del cacao desde el punto de vista fisiológico. In: Proc. 7a Conf. Interamer. de Cacao, Palmira, Colombia, pp.294-303.

Alvim PT (1960) Las necesidades de água del cacao. Turrialba 10:6-16.

Alvim (1973) Pesquisas com o cacaueiro no Brasil. Ciên. Cult. 25:409-424.

Alvim PT (1977) Cacao. In: Alvim PT, Kozlowski TT (eds), Ecophysiology of Tropical Crops, pp.279-313, Academic Press, London.

Alvim PT (1988) Relações entre fatores climáticos e produção do cacaueiro. In: Proc. 10th Int. Cocoa Res.
Conf., Santo Domingo, Dominican Republic, pp.159167.

Alvim PT (1989a) Tecnologias apropriadas para a agricultura nos trópicos úmidos. Agrotrópica 1:5-26.

Alvim R (1989b) O cacaueiro (Theobroma cacao L.) em sistemas agrossilviculturais. Agrotrópica 1:89-103.

Alvim R, Alvim PT (1976) Hidroperiodicidade dos fluxos foliares do cacaueiro. In: Informe Técnico, Ilhéus, Brasil, pp.42-48.

Alvim PT, Alvim R (1978) Relation of climate to growth periodicity in tropical trees. In: Tomlinson PB, Zimmermann MH (eds), Tropical Trees as Living Systems, pp.445-464. Cambridge University Press, Cambridge.

Alvim PT, Machado AD, Vello F (1974a) Physiological responses of cacao to environmental factors. Rev. Theobroma 4: 3-25.

Alvim R, Alvim PT, Lorenzi R, Saunders PF (1974b) The possible role of abscisic acid and cytokinins in growth rhythms of Theobroma cacao L. Rev. Theobroma 4:3-12.

Alvim R, Nair PKR (1986) Combination of cacao with other plantation crops: an agroforestry system in Southeast Bahia, Brazil. Agrofor. Syst. 4:3-15.

Alvim PT, Pereira CP (1965) Sombra e espaçamento nas plantações de cacau no estado da Bahia e Centro de Pesquisas do Cacau. In: Relatório Anual, Ceplac/ Cepec, Ilhéus, Brasil, pp.18-19.

Alvim R, Alvim PT, Lorenzi R, Saunders PF (1974) The possible role of abscisic acid and cytokinins in growth rhythms of Theobroma cacao L. Rev. Theobroma 4:3-12.

Amorim SM, Valle RR (1992) Efeito da temperatura radicular na resistência ao movimento d'água no cacaueiro. Acta Bot. Bras. 6:55-64.

Amorim SMC, Valle RR (1993) Absorção e resistência ao movimento da água no cacaueiro. Pesq. Agropec. Bras. 28: 907-913.

Anderson JM, Ingram JSI (1993) Tropical Soil Biology and Fertility: A Handbook of Methods. 2th ed. CAB, United Kingdom.

Aneja M, Gianfagna T, Ng E, Badilla I (1992) Carbon dioxide and temperature influence pollen germination and fruit set in cocoa. HortScience 27:1038-1040.

Aneja M, Gianfagna T, Ng E, Badilla I (1994) Carbon dioxide treatment partially overcomes selfincompatibility in a cacao genotype. HortScience 29:15-17. 
Aneja M, Gianfagna T, Ng E (1999) The roles of abscisic acid and ethylene in the abscission and senescence of cocoa flowers. Plant Growth Regul. 27:149-155.

Anim-Kwapong GJ (2003) Potential of some neotropical Albizia species as shade trees when replanting cacao in Ghana. Agrofor. Syst. 58:185-193.

Asomaning EJA, Kwakwa RS, Hutcheon WV (1971) Physiological studies on an Amazon shade and fertilizer trial at the Cocoa Research Institute of Ghana. Ghanaian J. Agric. Sci. 4:47-64.

Atanda OA (1972) Correlation studies in Theobroma cacao L. Turrialba 22:81-89.

Baker NR, Hardwick K (1973) Biochemical and physiological aspects of leaf development in cocoa (Theobroma cacao). I. Development of chlorophyll and photosynthetic activity. New Phytol. 72:13151324.

Baker NR, Hardwick K (1974) A model for the development of photosynthetic units in cocoa leaves. Proc. 3th Int. Congress Photosynthesis, Rehovot, Israel, pp.1897-1906.

Baker NR, Hardwick K (1975) Biochemical and physiological aspects of leaf development in cocoa (Theobroma cacao). III. Changes in soluble sugar content and sucrose synthesizing capacity. New Phytol. 75:519-524.

Baker NR, Hardwick K (1976) Development of photosynthetic apparatus in cocoa leaves. Photosynthetica 10:361-366.

Baker NR, Hardwick K, Jones P (1975) Biochemical and physiological aspects of leaf development in cocoa (Theobroma cacao). II. Development of chloroplast ultrastructure and carotenoids. New Phytol. 75:513518.

Baker RP, Hasenstein KH, Zavada MS (1997) Hormonal changes after compatible and incompatible pollination in Theobroma cacao L. HortScience 32:1231-1234.

Balasimha D (1988) Water relations, growth and other indicators of plant water stress in cocoa under drought. In: Proc. 10th Int. Cocoa Res. Conf., Santo Domingo, Dominican Republic, pp.215-217.

Bartley BGD (1969) Selfing of self-incompatible trees. In: Annual Report on Cacao Research. Trinidad, pp.22-23.

Bartley BGD (1970) Yield variation in the early productive years in trials with cacao (Theobroma cacao L.) Euphytica 19:199-206.
Bartley BGD (2005) The genetic diversity of cacao and its utilization. CABI Publishing, Wallingford, UK.

Batista LP, Alvim R (1981) Efeitos da intensidade luminosa e do genótipo sobre o crescimento em altura do fuste do cacaueiro. Rev.Theobroma 11:61-76.

Beer JW (1987) Advantages, disadvantages and desirable characteristics of shade trees for coffee, cacao and tea. Agrofor. Syst. 5:3-13.

Beer JW, Bonneman A, Chávez W, Fassbender HW, Imbach AC, Martel I (1990) Modelling agroforestry systems of cacao (Theobroma cacao) with laurel (Cordia alliodora) or poró (Erythrina poeppigiana) in Costa Rica. V. Productivity indices, organic material models and sustainability over ten years. Agrofor. Syst. 12:229-249.

Beer J, Muschler R, Kass D, Somarriba E (1998) Shade management in coffee and cacao plantations. Agrofor. Syst. 38:139-164.

Bergman JF (1969) The distribution of cacao cultivation in pre-columbian America. Ann. Assoc. Geograph. 59:85-96.

Bertolde FZ (2007) Respostas fisiológicas ao alagamento do substrato e diversidade genética molecular de clones de Theobroma cacao L. Ilhéus, Universidade Estadual de Santa Cruz, M.Sc. dissertation.

Bonaparte EENA (1973) An agronomist's assessment of recent research findings and their implications for cocoa production. In: Proc. Cocoa Econ. Res. Conf., Legon, Ghana, pp.73-85.

Bonaparte EENA (1975) Yield gradients in cocoa (Theobroma cacao L.) shade and fertilizer experiments. Acta Hort. 49:251-257.

Bonaparte EENA, Ampofo, S (1977) The cacao microclimate. In: Proc. 5th Int. Cocoa Res. Conf., Ibadan: CRIN, pp. 210-215.

Bosshart RP, von Uexkull HR (1987) Some occasionally overlooked criteria for assessing fertilizer requirements of high yielding cocoa. In: Seminar on Palm Kernel Utilization and Recent Advances in Cocoa Cultivation, Sawan, Sabah Malaysia, 29p.

Boyer J (1970) Influence des régimes hydrique, radiatif et thermique du climat sur l'activité végétative et la floraison de cacaoyers cultivés au Cameroun. Café Cacao Thé 14:189-201.

Brito AM, Silva GCV, Almeida CMVC, Matos PGG (2002) Sistemas agroflorestais com o cacaueiro: uma tentativa 
de busca do desenvolvimento sustentável do estado do Amazonas, Brasil. Agrotrópica 14:61-72.

Byrne PN (1972) Cacao shade spacing and fertilizing trial in Papua and New Guinea. In: Proc. 4th Int. Cocoa Res. Conf., St. Augustine, Trinidad and Tobago, pp.275286.

Cadima Zevallos A, Alvim PT (1983) Avaliação da transpiração do cacaueiro através de variações na umidade do solo. Rev. Theobroma 12:43-48.

Cazorla IM, Aidar T, Milde LCE (1989) Perfis do lançamento foliar, da floração, da bilração e de estágios do fruto do cacaueiro no Estado da Bahia, no período de 1987/1988. In: Boletim Técnico, Ceplac/Cepec, Ilhéus, Brasil, 58p.

Costa LCB, Almeida A-AF, Valle RR (1998) Crescimento, teor de clorofila e estrutura anatômica em plântulas de Theobroma cacao submetidas a diferentes irradiâncias e doses de nitrogênio. Agrotrópica 10:21-30.

Costa LCB, Almeida A-AF, Valle RR (2001) Gas exchange, nitrate assimilation and dry-matter accumulation of Theobroma cacao seedlings submitted to different irradiances and nitrogen levels. J. Hort. Sci. Biotechnol. 762:224-230.

Couprie F (1972) Étude de certains aspects de l'ecophysiologie du cacaoyer liés a la productivité en Uganda. Café Cacao Thé 16:31-41.

Cuatrecasas J (1964) Cacao and its allies: a taxonomic revision of the genus Theobroma. Bulletin of the United States National Museum. Smithsonian Institution Press, Washington, 35: 379-614.

Cunningham RK, Lamb J (1959) A cocoa shade and manurial experiment at the West African Cocoa Research Institute, Ghana. I. 1st year. J. Hort. Sci. 34:14-22.

Cunningham RK, Burridge JC (1960) The growth of cacao (Theobroma cacao) with and without shade. Ann. Bot. 24:458-462.

Cunningham RK, Arnold PW (1962) The shade and fertilizer requirements of cacao (Theobroma cacao) in Ghana. J. Sci. Food Agric. 13:213-221.

Cunningham RK (1963) What shade and fertilizers are needed for good cocoa production. Cocoa Growers Bull. 1:11-16.

Da Matta FM, Loos RA, Rodrigues R, Barros RS (2001) Actual and potential photosynthetic rates of tropical crop species Rev. Bras. Fisiol. Veg. 13:24-32
Daswir HAS, Dja'far D (1988) Analysis of cacao shaded with coconut (Cocos nucifera) compared with Leucaena glauca in North Sumatra. Bull. Perkebunan 19:99-106.

Daymond AJ (2000) An investigation into physiological parameters underlying yield variation between different varieties of cocoa (Theobroma cacao L.). UK, University of Reading, PhD thesis.

Daymond AJ, Hadley P, Machado RCR, Ng E (2002a) Canopy characteristics of contrasting clones of cacao (Theobroma cacao). Exp. Agric. 38:359-367.

Daymond AJ, Hadley P, Machado RCR, Ng E (2002b) Genetic variability in partitioning to the yield component of cacao (Theobroma cacao L.). HortScience 37:799-801.

Daymond AJ, Hadley P (2004) The effects of temperature and light integral on early vegetative growth and chloroplyll fluorescence of four contrasting genotypes of cacao (Theobroma cacao). Ann. Appl. Biol. 145:257-262.

de Nettancourt D (1977) Incompatibility in Angiosperms. Springer-Verlag, New York.

Deng X, Joly RJ, Hahn DT (1989) Effects of plant water deficit on the daily carbon balance of leaves of cacao seedlings. Physiol. Plant. 77:407-412.

Deng X, Joly RJ, Hahn DT (1990) The influence of plant water deficit on distribution of ${ }^{14} \mathrm{C}$-labeled assimilates in cacao seedlings. Ann. Bot. 66:211-217.

Dias LAS, Kageyama PY (1997) Temporal stability of multivariate genetic divergence in cacao (Theobroma cacao L.) in Southern Bahia conditions. Euphytica 93:181-187.

Dias LAS, Kageyama PY, Castro GCT (1997) Divergência genética multivariada na preservação de germoplasma de cacau (Theobroma cacao L.). Agrotrópica 9:29-40.

Evans H, Murray DB (1953) A shade and fertilizer experiment on young cocoa. In: Annual Rep. Cocoa Res., Imp. Coll. Trop. Agric., British Caribbean, Trinidad, pp. 67-76.

Fernandes EN, Vinha SG (1984) Recomposição florística do Parque zoobotânico do Centro de Pesquisas do Cacau. Rev. Theobroma 14:1-25.

Galyuon IKA, McDavid CR, Lopez FB, Spence JA (1996a) The effect of irradiance level on cocoa (Theobroma cacao L.): I. Growth and leaf adaptations. Trop. Agric. 73:23-28. 
Galyuon IKA, McDavid CR, Lopez FB, Spence JA (1996b) The effect of irradiance level on cacao (Theobroma cacao L.): II. Gas exchange and chlorophyll fluorescence. Trop. Agric. 73:29-33.

Gama-Rodrigues AC, Valle RR, Rossiello ROP (1995) Crescimento, trocas gasosas e relações hídricas de plântulas de cacau em função de diferentes fontes de potássio. Rev. Bras. Ciên. Solo 19:387-393.

Garcia JR (1973) Estudo de alguns índices de crescimento e produtividade para seleção juvenil em híbridos de cacau. Turrialba, IICA, M.Sc. dissertation.

Garcia JR, Nicolella G (1985) Correlação entre algumas medidas dendrométricas, origem genética e produção de frutos em cacaueiros. Rev. Theobroma 15:113-124.

Greathouse DC, Laetsch WM, Phinney BO (1971) The shoot-growth rhythm of a tropical tree, Theobroma cacao. Am. J. Bot. 58:281-286.

Glendinning DR (1960) Selfing of self-incompatible cocoa. Nature 187: 170.

Guers J (1985) Potentialités photosynthétiques du cacaoyer (Theobroma cacao L.) en fonction de l'eclairement, de la température et du $\mathrm{CO}_{2}$ ambiant. Café Cacao Thé 29:245-254.

Hadley P, End M, Taylor ST, Pettipher GL (1994) Environmental regulation of vegetative and reproductive growth in cocoa grown in controlled glasshouse conditions. In: Proc. 11th Int. Cocoa Res. Conf., Yamoussoukro, Côte D’Ivoire, pp. 319-331.

Hardwick K, Baker NR, Bird KJ (1981) Control of chloroplast formation and photosynthetic performance in developing cocoa (var. Amelonado and Amazon) leaves. Proc. 7th Int. Cocoa Res. Conf., Douala, Cameroon, pp.135-42.

Hasenstein KH, Zavada MS (2001) Auxin modification of the incompatibility response in Theobroma cacao. Physiol. Plant. 112:113-118.

Hurst WJ, Tarka SM Jr, Powis TG, Valdez FJr, Hester TR (2002) Cacao usage by the earliest Maya civilization. Nature 418:289-290.

Hutcheon WV (1973) Breeding for tolerance of exposure and the ability to respond to increased radiation. In: Annual Report, Cocoa Res. Inst., Ghana, pp.203-204.

Hutcheon WV (1976) Photosynthesis of cacao. In: Annual Report, Cocoa Res. Inst., Ghana, pp.186-190.

Hutcheon WV (1977) Growth and photosynthesis of cocoa in relation to environmental and internal factors.
In: Proc. 5th Int. Cocoa Res. Conf., Ibadan, Nigeria, pp.222-232.

ICCO (2007) Annual report. 43 p.

Isaac ME, Timmer VR, Quashie-Sam SJ (2007) Shade tree effects in an 8-year-old cocoa agroforestry system: biomass and nutrient diagnosis of Theobroma cacao by vector analysis. Nutr. Cycl. Agroecosyst. 78:155165.

Iserentant R (1976) Contribution à l'étude de la croissance du cacaoyer. Bull. Soc. Bot. Belg. 109:55-59.

Iwaro AD, Singh V, Barath S, Jugmohan N (2001) Germplasm evaluation at the International Cocoa Genebank. Trinidad for resistance to Phytophthora pod rot. In: Annual Report 2000 of the Cocoa Research Unit., University of the West Indies, Trinidad, pp.3440.

Joly RJ (1988) Physiological adaptations for maintaining photosynthesis under water stress in cacao. In: Proc. 10th Int. Cocoa Res. Conf., Santo Domingo, Dominican Republic, pp.199-203.

Khan MN, Patterson GR, Matlick BR (1988) Effect of supplemental water supplied through drip irrigation on cocoa yield at Lummingbird, Hershey, Ltd., Belize, C.A. In: Proc. 10th Int. Cocoa Res. Conf., Santo Domingo, Dominican Republic, pp.185-191.

Kummerow J, Kummerow A, Alvim PT (1981) Root biomass in a mature cacao (Theobroma cacao L.) plantation. Rev. Theobroma 11:77-86.

Kummerow J, Kummerow M, Silva WS (1982) Fine-root growth dynamics in cacao (T. cacao). Plant Soil 65:193201.

Lachenaud P, Mooleedhar V, Couturier C (1997) Les cacaoyers spontanés de Guyane. Nouvelles prospections. Plant. Rech. Dévelop. 4:25-30.

Lanaud C, Sounigo O, Amefia YK, Paulin D, Lachenaud P, Clement D (1987) Nouvelles données sur le fonctionnement du système d'incompatibilité du cacoyer et ses conséquences pour la sélection. Café Cacao Thé 31:267-277.

Lee DW, Brammeier S, Smith AP (1987) The selective advantages of anthocyanins in developing leaves of mango and cacao. Biotropica 19:40-49.

Leite RMO, Alvim R, Alvim PT (1980) Ação do vento e da radiação solar na ruptura do pulvino foliar do cacaueiro. Rev. Theobroma 104:235-251.

Leite JO, Cadima Zevallos AC (1991) Rainwater, water 
table and soil moisture in a hillslope. In: Proc. Int. Conf. Rain Water Cistern Syst., Keelung, Taiwan, pp.381-386.

Leite JO, Valle RR (2000) Relações entre a precipitação, o lençol freático e a produção de cacau na Bahia. Agrotrópica 12:67-74.

Liyanage LVK (1985) Rationale for intercropping. Coconut Bull. 2:31-35.

Lobão DE, Setenta WC, Lobão ESP, Curvelo K, Valle RR (2007) Cacau cabruca: sistema agrossilvicultural tropical. In: Valle RR (ed), Ciência, Tecnologia e Manejo do Cacaueiro, pp.290-323, Gráfica e Editora Vital Ltda, Ilhéus.

Machado RCR, Alvim PT (1981) Effects of soil water deficit on the flushing, flowering and water status of cacao trees. Rev. Theobroma 11:183-191.

Machado RCR (1986) Carbohydrate as a factor controlling leaf development in cocoa. UK, University of Liverpool. PhD thesis.

Machado RCR, Hardwick K (1987) Dynamics and histology of individual leaf and whole flush development yield clues on the control of the cocoa flush cycle. In: Proc. 10th Int. Cocoa Res. Conf., Santo Domingo, Dominican Republic, pp.143-149.

Machado RCR, Hardwick K (1988) Does carbohydrate availability control flush growth in cocoa? In: Proc. 10th Int. Cocoa Res. Conf., Santo Domingo, Dominican Republic, pp.151-157.

Mariano AH, Monteiro WR (1982) Melhoramento genético do cacau - avaliação preliminar de cultivares, ensaio 30. In: Informe Técnico, Comissão Executiva do Plano da Lavoura Cacaueira, Centro de Pesquisas do Cacau, Ilhéus, Brazil, pp.5-7.

Marita JM, Nienhuis J, Pires JL, Aitken WM (2001) Analysis of genetic diversity in Theobroma cacao with emphasis on witches' broom disease resistance. Crop Sci. 41:1305-1316.

Martin S (2006) Cacao in ancient Maya religion: first fruit from the maize tree and other tales from the underworld. In: McNeil CL (ed), Chocolate in Mesoamerica: A cultural History of Cacao, pp. 154-183. University Press of Florida, Gainnesville.

Martins DV (1976) Variação sazonal de alguns elementos minerais na seiva xilemática do cacaueiro (Theobroma cacao L.). Salvador, Universidade Federal da Bahia, M.Sc. dissertation.

Medeiros ZMD, Silva WS, Vogel M (1987) Atividades das raízes finas de cacaueiros em função da hidroperiodicidade. Rev. Theobroma 17:233-241.

Merkel U, Müller MW, Serrano-Minar P, Biehl B (1994) Light intensity influence on the characteristics of the photosynthetic apparatus from cocoa tree (Theobroma cacao L.) during leaf development. In: Proc.11th Int. Cocoa Res. Conf., Yamoussoukro, Côte D’Ivoire, pp.645-653.

Mielke MS, Almeida A-AF, Gomes FP (2005) Photosynthetic traits of five neotropical rainforest tree species: interactions between light response curves and leaf-to-air vapour pressure deficit. Braz. Arch. Biol. Technol. 48:815-824.

Miranda RAC, Milde LCE, Bichara AL, Cornell S (1994) Daily characterisation of air temperature and relative humidity profiles in a cocoa plantation. Pesq. Agropec. Bras. 29:345-353.

Miyaji K, Silva WS, Alvim PT (1990) Longevity and productivity of leaves of Theobroma cacao L. in relation to their position within the canopy under different shading. In: Abstracts of the V International Congress of Ecology, Yokohama, pp.273.

Miyaji K-I, Silva WS, Alvim PT (1997a) Productivity of leaves of a tropical tree, Theobroma cacao, grown under shading, in relation to leaf age and light conditions within the canopy. New Phytol. 137:463472.

Miyaji K-I, Silva WS, Alvim PT (1997b) Longevity of leaves of a tropical tree, Theobroma cacao, grown under shading, in relation to position within the canopy and time of emergence. New Phytol. 135:445454.

Motamayor JC (2001) Etude de la diversité génétique et de la domestication des cacaoyers du groupe Criollo (Theobroma cacao L.) à l'aide de marqueurs moléculaires. Paris, Université Paris XI, PhD thesis.

Motamayor JC, Risterucci AM, Lopez PA, Ortiz CF, Moreno A, Lanaud C (2002) Cacao domestication. I. The origin of the cacao cultivated by the Mayas. Heredity 89:380-386.

Müller MW, Serrano-Minar P, Biehl B (1992) Photosynthetic characteristics during development of leaves from Theobroma cacao L. Physiol. Plant. 853:A105, 599.

Müller MW, Gama-Rodrigues AC (2007) Sistemas agroflorestais com cacaueiro. In: Valle RR (ed), Ciência, 
Tecnologia e Manejo do Cacaueiro, pp.246-271. Gráfica e Editora Vital Ltda, Ilhéus.

Muñoz F, Beer J (2001) Fine root dynamics of shaded cacao plantations in Costa Rica. Agrofor. Syst. 51:119130.

Murray DB, Nichols R (1966) Light, shade and growth in some tropical plants. In: Bainbridge R, Evans GC, Rackham O (eds), Light as an Ecological Factor, pp.249-263, Blackwell, Oxford.

Ng E (1982) Potential cacao photosynthetic productivity. In: Proc. 8th Int. Cacao Res. Conf., Cartagena, Colombia, pp.235-244.

Okali DUU, Owusu JK (1975) Growth analysis and photosynthetic rates of cocoa (Theobroma cacao L.) seedlings in relation to varying shade and nutrient regimes. Ghana J. Agric. Sci. 8:51-67.

Orchard JE (1978) Efeito do K na transpiração, na resistência difusiva de folha e crescimento em plântulas de Theobroma cacao L. In: Informe técnico, Cepec/Ceplac, Ilhéus, Brasil, pp.61-64.

Orchard JE, Collin HA, Hardwich K (1980) Biochemical and physiological aspects of leaf development in cocoa (Theobroma cacao). IV. Changes in growth inhibitors. Plant Sci. Lett. 18:299-305.

Orchard JE, Collin HA, Hardwich K (1981) Biochemical and physiological aspects of leaf development in cocoa (Theobroma cacao). V. Changes in auxins and cytokinins. Café Cacao Thé 25:25-28.

Orchard JE, Saltos MR (1988) The growth and water status of cacao during its first year of establishment under different methods of soil water management. In: Proc. 10th Int. Cocoa Res. Conf., Santo Domingo, Dominican Republic, pp.193-198.

Owusu JK (1978) Light requirements of cocoa: a review. In: Proc. Int. Conf. Cocoa and Coconuts, Kuala Lumpur, Malaysia, pp.112-121.

Padi B, Owusu JK (1998) Towards an Integrated Pest Management for Sustainable Cocoa production in Ghana. Paper from workshop held in Panama, 3/30-4/2. Smithsonian Institution. Washington, D.C.

Pound FJ (1932) Studies of fruitfulness in cacao. 2. Evidence for partial sterility. In: First Annual Report on Cacao Research. Trinidad, pp. 26-28.

Raja Harun RM, Hardwick K (1988a) The effects of prolonged exposure to different light intensities on the photosynthesis of cocoa leaves. In: Proc. 10th Int.
Cocoa Res. Conf., Santo Domingo, Dominican Republic, pp.205-209.

Raja Harun RM, Hardwick K (1988b) The effect of different temperatures and water vapour pressure deficits on photosynthesis and transpiration of cocoa leaves. In: Proc. 10th Int. Cocoa Res. Conf., Santo Domingo, Dominican Republic, pp.211-214.

Rehem BC (2006) Respostas fisiológicas de clones de Theobroma cacao L. ao alagamento do substrato. Ilhéus, Universidade Estadual de Santa Cruz, M.Sc. dissertation.

Rodriguez RM, Carvajal JF, Machicado M, Jimenez M (1963) Nutritional requirements of the cocoa plant during a yearly cycle. Cacao 8:1-7.

Rosenberg DE, Marcotte, TP (2005) Land-use system modeling and analysis of shaded cacao production in Belize. Agrofor. Syst. 64:117-129.

Sale PJM (1968) Flushing and leaf growth of cacao under controlled temperature conditions. J. Hort. Sci. 43:475489.

Sale PJM (1969) Flowering of cacao under controlled temperature conditions. J. Hort. Sci. 44: 163-173.

Sale PJM (1970) Growth, flowering, and fruiting of cacao under controlled soil moisture conditions. J. Hort. Sci. 45:99-118.

Santana MBM, Igue K (1979) Composição química das folhas do cacaueiro em função da idade e da época do ano. Rev. Theobroma 9:63-76.

Sena Gomes AR, Kozlowski TT (1986) The effects of flooding on water relations and growth of Theobroma cacao var. catongo seedlings. J. Hort. Sci. 61:265-276.

Sena Gomes AR, Kozlowski TT, Reich PB (1987) Some physiological responses of Theobroma cacao var. catongo seedlings to air humidity. New Phytol. 107:591-602.

Silva WS, Kummerow J (1998) Fine-root growth and longevity in a cacao (Theobroma cacao L.) plantation. Agrotrópica 10:31-34.

Sleigh PA, Hardwick K, Collin HA (1981) A study of growth periodicity in cocoa seedlings with particular emphasis on the root system. Café Cacao Thé 25:169172.

Snoeck J (1979) Relations entre les récoltes mensuelles des cacaoyers et les facteurs du climat en Côte d'Ivoire, études preliminaires. Café Cacao Thé 23:277282. 
Soria VJ (1963) Observaciones sobre las variedades y cultivares de cacao en Bahia, Brasil. Cacao 8:1-6.

Soria VJ (1964) El vigor hibrido y su uso en mejoramiento genético de cacao. Fitotec. Latinoam. 1:59-78.

Soria JN (1970) Principal varieties of cocoa cultivated in tropical America. Cocoa Growers’ Bull. 19:12-21.

Soria SJ, Wirth WW, Pinho AFS (1985) A polinização do cacaueiro no Recôncavo Baiano, Brasil. 1. Entomofauna comparada com a do Sul da Bahia. Rev. Theobroma 15:1-7.

Sounigo O, Lachenaud P, Bastide P, Cilas C, N'Goran J, Lanaud C (2003) Assessment of the value of doubled haploids as progenitors in cocoa (Theobroma cacao L.) breeding. J. Appl. Genet. 44:339-353.

Stevenson A (1987) Cocoa: fundamental report. E.F. Hutton Futures Division.

Taylor SJ, Hadley P (1987) Relation between root and shoot growth in cocoa (Theobroma cacao) grown under different shade regimes. In: Proc. 10th Int. Cocoa Res. Conf., Santo Domingo, Dominican Republic, pp.77-183.

Thong KC, Ng WL (1980) Growth and nutrients compositions of monacrop cocoa plants on inland Malaysian soils. In: Proc. Int. Conf. Cocoa and Coconuts, Kuala Lumpur, Malaysia, pp.262-286.

Valle RR, Silva WS, Miranda RAC (1987) Stomatal resistance and transpiration rates of shaded and unshaded cacao trees. Rev. Theobroma 17:175-187.

Valle RR, Almeida A-AF, Leite RMO (1990) Energy costs of flowering, fruiting and cherelle wilt in cacao. Tree Physiol. 6:329-336.

Vello F, Garcia JR, Magalhães WS, Nascimento IF (1972) Competição de cacaueiros híbridos. In: Informe Técnico, Comissão Executiva do Plano da Lavoura Cacaueira, Centro de Pesquisas do Cacau, Ilhéus, Brazil, pp.17-24.
Vernon AJ (1967) Yield and light relationships in cocoa. Trop. Agric. 44:223-228.

Vernon AJ, Sundaram S (1972) Current cocoa research. In: Proc. 4th Int. Cocoa Res. Conf., St. Augustine, Trinidad and Tobago, pp.689-693.

Vieira DR, Müller MW (2001) Estudo comparativo da produção de cacaueiros autocompatíveis e autoincompatíveis do híbrido SIAL 169 x P7 no Recôncavo da Bahia. In: Proc. 13th Int. Cocoa Res. Conf., Kota Kinabalu, Malaysia, pp. 175-181.

Vogel M (1975) Recherche du déterminisme du rythme de croissance du cacoayer. Café, Cacao, Thé 19:265290.

Vogel M, Machado RCR, Alvim PT (1982) Remoção de órgãos jovens como método de avaliação das interações fisiológicas no crescimento, floração e frutificação do cacaueiro. In: Proc. 8th Int. Cocoa Res. Conf., Cartagena, Colombia, pp.215-222.

Warren J, Sunita MK (1995) Isozyme markers for selfincompatibility and yield in Theobroma cacao. Heredity 74:354-356.

Whatley JM (1992) Plastid development in distinctively coloured juvenile leaves. New Phytol. 120:417-426.

Wood GAR (1985) Environment. In: Wood GAR, Lass RA (eds), Cocoa, pp.38-78. Longman, London.

Yamada MM, Guries, RP (1998) Mating system analysis in cacao (Theobroma cacao L.). Agrotrópica 10:165-176.

Yapp JHH, Hadley P (1994) Inter-relationships between canopy architecture, light interception, vigour and yield in cocoa: implications for improving production efficiency. In: Proc. Int. Cocoa Conf.: Challenges in the 90s, pp.332-350.

Zuidema PA, Leffelaar PA, Gerritsma W, Mommer L, Anten NPR (2005) A physiological production model for cocoa (Theobroma cacao): model presentation, validation and application. Agric. Syst. 84:195-225. 